\title{
Review \\ Roles of the CXCL8-CXCR1/2 Axis in the Tumor
Microenvironment and Immunotherapy
}

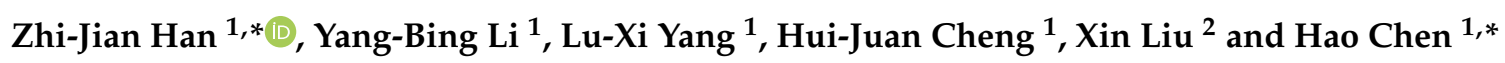

1 The Key Laboratory of the Digestive System Tumors of Gansu Province, Tumor Center, Lanzhou University Second Hospital, Lanzhou 730000, China; liyangbing3906@yeah.net (Y.-B.L.); momoer1988@yeah.net (L.-X.Y.); chenghj20@lzu.edu.cn (H.-J.C.)

2 The Second Clinical Medical College, Lanzhou University, Lanzhou 730000, China; liux21@lzu.edu.cn

* Correspondence: ery_hanzhj@lzu.edu.cn (Z.-J.H.); ery_chenh@lzu.edu.cn (H.C.); Tel.: +86-186-9310-9388 (Z.-J.H.); +86-150-0946-7790 (H.C.)

Citation: Han, Z.-J.; Li, Y.-B.; Yang, L.-X.; Cheng, H.-J.; Liu, X.; Chen, H. Roles of the CXCL8-CXCR1/2 Axis in the Tumor Microenvironment and Immunotherapy. Molecules 2022, 27, 137. https://doi.org/10.3390/ molecules27010137

Academic Editors: Vaclav Vetvicka and Enrico Millo

Received: 28 October 2021

Accepted: 23 December 2021

Published: 27 December 2021

Publisher's Note: MDPI stays neutral with regard to jurisdictional claims in published maps and institutional affiliations.

Copyright: (C) 2021 by the authors. Licensee MDPI, Basel, Switzerland. This article is an open access article distributed under the terms and conditions of the Creative Commons Attribution (CC BY) license (https:// creativecommons.org/licenses/by/ $4.0 /)$.

\begin{abstract}
In humans, Interleukin-8 (IL-8 or CXCL8) is a granulocytic chemokine with multiple roles within the tumor microenvironment (TME), such as recruiting immunosuppressive cells to the tumor, increasing tumor angiogenesis, and promoting epithelial-to-mesenchymal transition (EMT). All of these effects of CXCL8 on individual cell types can result in cascading alterations to the TME. The changes in the TME components such as the cancer-associated fibroblasts (CAFs), the immune cells, the extracellular matrix, the blood vessels, or the lymphatic vessels further influence tumor progression and therapeutic resistance. Emerging roles of the microbiome in tumorigenesis or tumor progression revealed the intricate interactions between inflammatory response, dysbiosis, metabolites, CXCL8, immune cells, and the TME. Studies have shown that CXCL8 directly contributes to TME remodeling, cancer plasticity, and the development of resistance to both chemotherapy and immunotherapy. Further, clinical data demonstrate that CXCL8 could be an easily measurable prognostic biomarker in patients receiving immune checkpoint inhibitors. The blockade of the CXCL8-CXCR1/2 axis alone or in combination with other immunotherapy will be a promising strategy to improve antitumor efficacy. Herein, we review recent advances focusing on identifying the mechanisms between TME components and the CXCL8-CXCR1/2 axis for novel immunotherapy strategies.
\end{abstract}

Keywords: interleukin-8; chemokine; tumor microenvironment; cancer-associated fibroblast; microbiome; CXC receptors 1 and 2; myeloid-derived suppressor cells; immunotherapy; neutrophile

\section{Introduction}

The tumor microenvironment (TME) has a close relationship with carcinogenesis but also provides fertile ground for tumor progression and metastasis [1,2]. However, our knowledge of cellular composition, organization, spatial distribution, interaction, and communication is limited concerning the TME. A great deal of evidence has confirmed the roles of interleukins [3] or chemokines, especially the CXCL8-CXCR1/2 axis, in proinflammation, tumor enhancement, and immunotherapy resistance [4].

Immunotherapy is proving effective in both hematological malignant and solid tumors [5]. Some therapies [6] include adoptive cellular transfer, cancer vaccines, and immune agonists; immune checkpoint inhibitors are effective in certain patients, but most patients have innate resistance or quickly acquire resistance [7]. A novel strategy or combination therapy response in vitro shows only a modest effect in vivo [8,9]. All of these indicate a possible resistance mechanism associated with the TME and more strategies to enhance the immunotherapy are very desirable [10]. Targeting the TME [11] instead of cancer cells has proved to be a successful therapeutic method, such as with the use of antiangiogenic drugs.

Two main research strategies relate to the TME. One has focused on the unique physicochemical characteristics of TME including hypoxia, acidic $\mathrm{pH}$, enhanced vascular 
permeability, and abnormal nutrient partitioning [12]. The other focuses on the components of the TME, especially cellular interactions [13]. Various cells in the TME build up a complex social network. Cytokines and chemokines have an important role in the communication of these cells through the interaction to their specific receptors. Intercellular interactions in the TME play central roles in determining the molecular mechanism of disease and response to therapy [14].

Here, we review the role of the CXCL8-CXCR1/2 axis in shaping the TME and its effect in cancer therapy, especially through interaction with CAFs, the microbiome, and immune cells. Advanced therapeutic approaches are discussed, including small molecule inhibitors and antibodies targeting the CXCL8-CXCR1/2 axis.

\section{Composition of TME}

The major components of the TME (Figure 1) are cancer cells, stromal cells, the extracellular matrix (ECM), blood vessels, lymphatic vessels, the microbiome, and signal molecules [15]. The stromal cells are mainly cancer-associated fibroblasts (CAFs), mesenchymal stem cells (MSCs), inflammatory cells or immune cells, vascular endothelial cells, pericytes, smooth muscle cells, and adipocytes [16]. Cancer progression often benefits from the presence of CAFs, myeloid-derived suppressor cells (MDSCs), and an immune repression TME. Non-malignant CAFs can also be targeted for cancer radionuclide imaging and therapy [17]. Stromal-immune niches were temporal and spatially organized in the TME $[18,19]$. Immune cells are the protagonist of tumor immunotherapy, including $\mathrm{T}$ cells, B cells, natural killer cells (NK), dendritic cells (DCs), neutrophils, macrophages, tumor-associated macrophages (TAMs), and MDSCs. CXCL8 can recruit myeloid cells to the TME and play a key role in forming the immunosuppressive microenvironment. Ample evidence showed that MDSCs and TAMs exert their tumor-promoting effects by suppressing T-cell functions and enhancing tumor proliferation, invasion, and metastasis. All these cells and microbiomes have a close relationship with cytokines and chemokines [20]. CXCL8-CXCR1/2 can interfere with the differentiation and function of stromal cells and immune cells in TME, ultimately affecting immunotherapy [21].
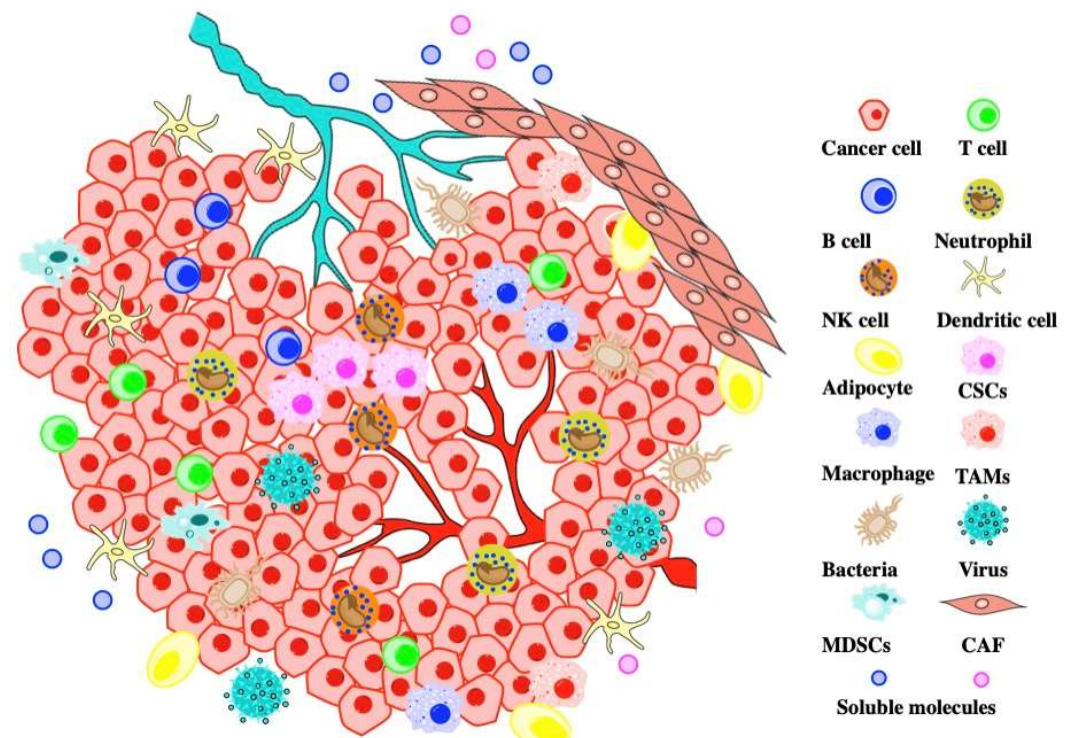

Figure 1. Various types of components in the TME of solid malignancies. The cellular composition of TME is mainly CAFs, cancer cells, immune cells, and the microbiome. All of the cells interact with each other via soluble molecules such as cytokines or chemokines and trafficking through blood vessels or lymphatic vessels (the abundance of each component is not illustrated here). 


\section{CXCL8-CXCR1/2 Signaling Pathway}

The proinflammatory cytokine CXCL8 was initially found as a chemotactic agent for neutrophils in inflammatory diseases. Through both autocrine and paracrine signaling, the CXCL8-CXCR1/2 axis can recruit the neutrophil to clear bacteria and protect the host from infection. Due to the similarity of the pathogenesis of inflammatory diseases and cancer, more researchers have focused on the roles of the CXCL8-CXCR1/2 axis in cancer [22].

CXCL8 is a peptide with 72 amino acids and has a critical N-terminal motif of GluLeu-Arg (ELR). CXCL8 can be secreted by fibroblasts, CAFs, endothelial cells, epithelial cells, DCs, monocytes, macrophages, and cancer cells [23]. CXCL8 signals through two cell-surface receptors of CXCR1 and CXCR2. CXCR1 and CXCR2 are the G-protein-coupled receptor for a group of C-X-C chemokines. CXCR1 interacts with CXCL6 and CXCL8, whereas CXCR2 interacts with CXCL1, CXCL2, CXCL3, CXCL5, CXCL6, CXCL7, and CXCL8. CXCL8-CXCR1/2 signaling with CAF, the microbiome, and immune cell help in recruiting granulocytes such as neutrophils and MDSCs to the site of the TME and contribute to tumor growth by enhancing angiogenesis and promoting cancer cell proliferation [24] and immune resistance [25] (Figure 2).

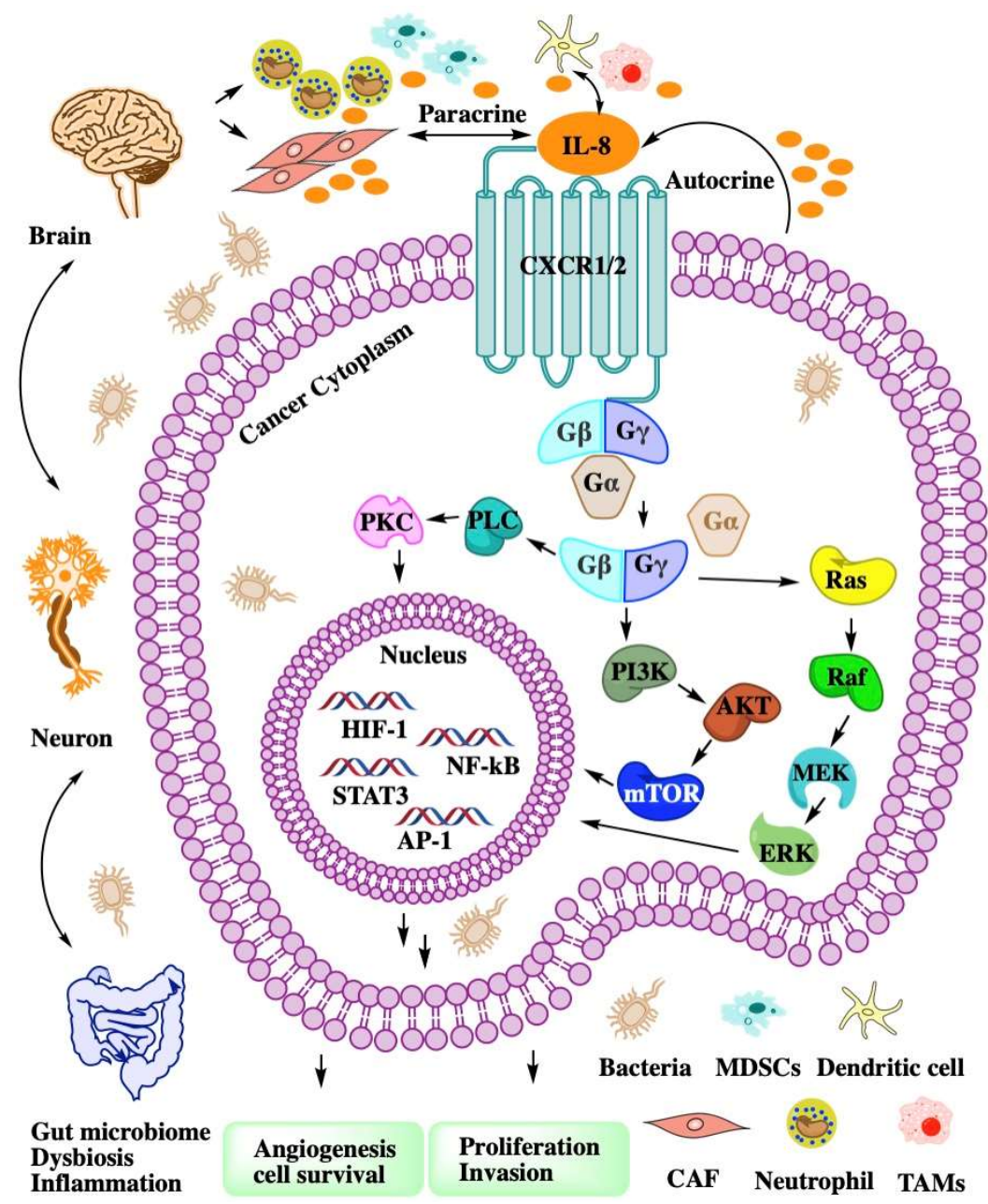

Figure 2. The intricate network of the CXCL8-CXCR1/2 axis in TME. CXCL8 binding to CXCR1/2 activates G-protein-mediated signaling cascades in cancer cell. CXCR1/2 activation leads to the dissociation of the $G \alpha$ subunit from the $G \beta \gamma$ subunits. The signal of $G \beta \gamma$ subunits activate kinase to enhance angiogenesis, proliferation, and invasion. Cancer cell autocrine CXCL8 to recruit MDSCs or neutrophil to TME. Dysbiosis or inflammation affects myeloid cell recruitment through the gutbrain axis. 


\subsection{Interactions of the CXCL8-CXCR1/2 Axis and CAF}

CAFs are activated fibroblast populations and the major cellular components of the TME in primary and metastatic cancers $[26,27]$. CAFs have different features from normal fibroblasts after infiltrating tumor tissue, such as enhanced proliferation and epigenetic changes to produce secreted factors [28]. CAFs are contributors to desmoplasia that can facilitate tumorigenicity, cancer cell proliferation, metastasis, and cancer immunotherapy resistance through complex interactions and intricate signaling [29] with other cell types in the TME [30].

The population of CAFs are highly heterogeneous because several progenitor cell types can be reprogrammed into CAFs [31]. Quiescent or resident fibroblasts are major progenitor cells of CAFs [32]. Hepatic [33] or pancreatic stellate cells [34] are the putative origin of CAFs. Adipocytes [35], endothelial cells [36], epithelial cells [37], and bone marrow cells [38] can be reprogrammed into CAFs. CAFs can also derive from multiple resident precursors, such as smooth muscle cells or mesenchymal stem cells [39]. Nevertheless, the precise origins of CAFs remain elusive because of the lack of lineage biomarkers.

CAFs have both tumor-promoting and tumor-suppressive functions [40]. The tumorsuppressive functions of CAFs [41] remain poorly understood. Part of the host defensive mechanism involves promotion of anticancer immunity, tumor-inhibitory signaling, tumorrestraining metabolism, and ECM-related physical barriers to tumor cell invasion and dissemination. Desmoplasia is the growth of fibrous or connective tissue in desmoplastic breast, lung, and pancreatic cancers. The desmoplastic reaction may form the desmoplasia or dense fibrosis around the tumor to restrict its growth and migration [42]. The mechanisms of tumor-promoting roles of CAFs are mainly regulatory functions via growth factors, cytokines, and chemokines contributing to angiogenesis; ECM remodeling; aberrant stroma, and an immunosuppressive TME [43]. Mass cytometry and single-cell analysis of pancreatic tumors and healthy pancreas samples found two stable and functionally distinct pancreatic fibroblast lineages. CD105-positive pancreatic fibroblasts promote tumor growth, but CD105-negative fibroblasts are highly tumor suppressive in a manner dependent on adaptive immunity [44].

CAF subsets have specialized secretory functions, such as cytokines, chemokines, and ECM molecules collagen I, which contribute to ECM remodeling and immunomodulatory function. Tumor-fibroblast interactions via soluble factors determine the final outcome of the tumorigenic process and affect the cancer therapy [45]. The CAF population is heterogeneous according to the cell origins, and the functional heterogeneity can be regulated by paracrine molecules such as CXCL8 and CXCR1/2 ligands [30]. CAFs can attract monocytes by secreting CXCL8 to enhance TAM enrichment and suppress NK cells' function in colorectal cancer [46]. In gastric cancer tissues of chemoresistant patients, CXCL8 was highly expressed and located in CAFs by immunohistochemistry assay. A high serum CXCL8 level was associated with poor response to cisplatin therapy in gastric cancer patients [47]. CAFs are major sources of chemokines (CXCL1 and CXCL8) that recruit granulocytes (TAM and PMN-MDSC) to tumors. Combining a selective CSF1R inhibitor (JNJ-40346527) with a CXCR2 antagonist (SB225002) blocked granulocyte recruitment and demonstrated a strong antitumor effect, which was further improved by the addition of antiprogrammed cell death protein 1 (PD-1) [48].

Chronic inflammation and proinflammatory cytokines tumor necrosis factor $\alpha(\mathrm{TNF} \alpha)$ and interleukin $1 \beta$ (IL-1 $\beta$ ) can induce the conversion of MSCs to inflammatory CAFs. These CAFs secrete prometastatic chemokines including CXCL6 and CXCL8 in Luminal-A breast cancer cells and enhance migration [49]. CXCL8 can induce normal ovarian fibroblasts to CAFs and stimulate xenograft tumor growth in mice. The ovarian cancer cell stemness was promoted by the CXCL8 secreted from CAFs through the Notch3 signaling pathway [50]. Gastric cancer extracellular vesicles transfer various miRNAs and induce chemokines such as CXCL1 and CXCL8 expression in CAFs. Aberrant chemokine CXCL1 and CXCL8 expression in CAFs was closely associated with tumor progression and poorer survival in gastric cancer patients [51]. CAFs demonstrate a high level of basal secretory autophagy in 
head and neck squamous cell carcinoma. Secretory autophagy is involved in the export of cellular inflammatory mediators such as IL-6 and CXCL8. Combination therapy using autophagy inhibition with cisplatin significantly reduced tumor volume [52].

Stromal cells such as CAFs and MSCs enhance the triple-negative subtype of breast cancer metastasis-related phenotypes, including angiogenesis, migratory, and invasive properties, by releasing inflammatory chemokines such as CCL2 and CXCL8 [53]. Notch 1 activation is required for the induction of CXCL8 in tumor-stroma interactions and consequently for prometastatic activities [54]. Androgen receptor signaling in CAFs affects prostate cancer cell migration mediated by CXCL8 and CCL2 [55]. CAFs express CXCR2 and respond to paracrine signals of pancreatic cancer cells by upregulating CXCR2 ligands such as CXCL1, CXCL7, and CXCL8. CXCR2 knockout in a pancreatic ductal adenocarcinoma syngeneic mouse model suppressed angiogenesis and induced an antitumor response, but increased CAF activation, fibrosis, and metastasis in a mutation-dependent manner [56].

The CAF response to chemotherapy is highly variable and may impact on cancer therapy outcome [57]. Traditional maximum-tolerated dose chemotherapy induces CAF activation and results in the expression and secretion of ELR motif-positive chemokines such as CXCL6 and CXCL8 [58]. These chemokines signal though CXCR2 on cancer cells to transform into tumor-initiating cells, thus promoting aggression and treatment resistance. While the same overall dose administered as a low-dose metronomic chemotherapy largely prevented CAF activation and enhanced treatment response, it improved survival in mice [58]. CAF-secreted IL-6 and CXCL8 induce Bromodomain-containing protein 4 (BRD4) protein expression and lead to chromatin remodeling and Bromodomain and Extraterminal (BET) inhibitor resistance in colorectal cancer (CRC). Inhibition of IL-6/CXCL8-JAK2 signaling sensitized BET inhibitors in a CRC mouse xenograft model [59]. Simultaneous blocking of IL-6 and CXCL8 can inhibit CAF-induced human melanoma cell invasiveness using neutralizing antibodies in a 3D spheroid invasion assay [60]. Senescent human fibroblasts can secrete IL-6 and CXCL8 to promote cancer cell invasion and metastasis [61]. Senescent CAFs are a pathologically relevant fibroblast population that secrete excess CXCL8 to promote pancreatic cancer invasion [62]. A new subset of $\mathrm{CD} 10^{+} \mathrm{GPR} 77^{+} \mathrm{CAFs}$ induce cancer stem cells' (CSCs) enrichment and chemoresistance by secreting IL-6 and CXCL8 in cancer. $\mathrm{CD} 10^{+} \mathrm{GPR} 77^{+} \mathrm{CAFs}$ constitute a supporting niche for CSCs, and its high expression correlates with poor survival in breast and lung cancer patients [63].

\subsection{Microbiome in the TME}

Commensal microbiota not only affect tumorigenesis, progression, and host metabolism but also shape the TME and regulate the efficiency of cancer therapy [64]. Bacteria induce an inflammatory response and stimulate epithelial cells to produce CXCL8, which can promote neutrophil recruitment. The mechanism of gut microbiome functions in cancer includes manipulating the gut epithelial barrier, modulating lymphoid organ activities, and regulating tumor immunity [65] and the TME via communication with various immune cells. The gut microbiota can signal to the central nervous system by producing hormones or immune-mediated signals through the gut-brain axis to affect tumor progression [66]. In a study of hundreds of hospitalized patients with cancer receiving allogeneic hematopoietic cell transplantation, the gut microbiota composition was closely associated with immune cell dynamics in humans after analyzing the daily changes of circulating neutrophil, lymphocyte, and monocyte counts [67].

\subsubsection{Dysbiosis and FMT}

Dysbiosis is the imbalance of human microbiota composition mainly caused by drug exposure (antibiotics [68] and non-antibiotics [69]), alcohol overdose [70], or inappropriate diet [71]. Dysbiosis of the salivary microbiome contributes to the progression of oral squamous cell carcinoma (OSCC) by increasing inflammatory cytokines such as IL-6, CXCL8, TNF- $\alpha$ [72]. Dysbiosis increased the severity of amebic colitis through decreasing 
CXCR2 expression and neutrophil recruitment to the gut [73]. Antibiotic-induced dysbiosis enhances distal tumor progression through ICAM-1-mediated suppression of effector CD8+ T-cell trafficking into the tumor [74]. A high-fat diet promoted carcinogenesis by altering the esophageal microenvironment and gut microbiome via CXCL8/CXCL1/KC chemokines [75]. Chronic gastrointestinal diseases such as inflammatory bowel diseases (IBD), primary sclerosing cholangitis (PSC), cirrhosis, and tumorigenesis are promoted during dysbiosis conditions, which are associated with intestinal barrier dysfunction. Gut dysbiosis and intestinal barrier dysfunction are commonly observed in patients with PSC. A commensal Gram-negative gut microbiome can control the accumulation of CXCR2 ${ }^{+}$ PMN-MDSC through the lipopolysaccharide (LPS)/TLR4/CXCL1 mechanism and promote cholangiocarcinoma [76].

Gut microbiota dysbiosis can be modulated through probiotics [77], fecal microbiota transplant (FMT) [78], engineered exogenous microbes, and bacteriophage therapy [79]. Preclinical and clinical evidence supports gut bacteria in modulating the efficacy of immunotherapy in cancers. Probiotic intervention in CRC patients altered the microbiota composition and increased microbial diversity [80]. Oral pretreatment with probiotic Bifidobacterium alleviates intestinal inflammation and colitis-associated cancer through CXCR2 signaling [81]. FMT promoted tumor response to anti-PD-1 immunotherapy in patients with refractory metastatic melanoma in a phase I clinical trial (NCT03353402). This study demonstrated an increased lamina propria infiltration of $\mathrm{CD} 68^{+}$cells. These increased antigen-presenting cells such as DCs in the gut could migrate into the TME through the lymphatic system and result in trafficking T cells into tumors [82]. Another single-arm phase I clinical trial (NCT03341143) enrolled sixteen patients with refractory metastatic melanoma, and demonstrated that the combination of FMT with anti-PD-1 therapy successfully induced persistent perturbation of the recipients' gut microbiome and reprogrammed the TME to overcome primary resistance to anti-PD-1. Higher percentages of CD56 $6^{+} \mathrm{CD} 8^{+} \mathrm{T}$ cells and mucosal-associated invariant T cells and lower percentages of CXCL8-producing myeloid cells were found both in PMBC and tumor samples after treatment [83]. LPS can stimulate the intestinal epithelial cells and activate proinflammatory signaling including phosphorylation of IRAK and MAP kinases and increased CXCL8 secretion [84].

\subsubsection{Intratumor Microbiome}

The intratumor microbiome is also an integral part of the TME and may play a critical role in shaping the TME, affecting tumorigenesis, progression, and tumor immunity in the TME and the response to immunotherapy [85]. Lung cancer is closely associated with local dysbiosis, chronic inflammation, and pulmonary infections. Commensal microbiota induce proliferation and activation of IL-17-producing $\gamma \delta \mathrm{T}$ cells to promote neutrophil infiltration and tumor development [86]. After a comparison of the inflammatory cytokine concentrations of saliva from head and neck squamous cell patients, CXCL8 and IL-1 $\beta$ were significantly high and positively correlated with the abundance of oral microbe C. albicans [87]. Irrespective of the gut microbe or intratumor bacteria, gaining a better understanding of their role in the TME and response to immune therapy may pave the way for novel treatment options for cancer patients.

\subsection{Crosstalk of the CXCL8-CXCR1/2 Axis and Immune Cells in the TME}

Both CAF and the microbiome work indirectly to affect immunotherapy efficacy. Cytotoxic T cells can directly kill the cancer cells that need the infiltration, activation, proliferation, and spatial distribution of T cells within the TME. However, tumors have evolved many methods of escaping immune attack through recruiting neutrophils, MDSCs, or TAMs to the TME by cytokines or chemokines. The CXCL8-CXCR1/2 axis has been shown to be tightly connected with the neutrophil or MDSC recruiting, and CXCL8 can directly or indirectly affect the function of almost all immune cell types, thereby influencing tumor development. DCs produce CXCL8 and express the CXCL8 receptors CXCR1 and 
CXCR2. Human malignant cells can also produce CXCL8 to attract and retain DC to the tumor tissue that eventually decreases antitumor immunity [88].

\subsubsection{Neutrophils, MDSCs, and NETs}

Neutrophils have many functions, such as phagocytosis, degranulation, reactive oxygen species (ROS) production, and extrusion of neutrophil extracellular traps (NETs) [89]. MDSCs contribute to tumor immune evasion through T-cell suppression, oxidative stress, and nutrient depletion. MDSCs are immature myeloid cells including monocytic (MMDSCs) and granulocytic (GrMDSCs) subsets. Interactions between CXCR2 and CXCR2 ligands attracted MDSC traffic to the TME and enhanced rhabdomyosarcoma progression in a murine model. CXCR2 inhibition prevented MDSC trafficking to the TME and improved the efficacy of anti-PD-1 therapy [90]. TNBC cell autocrine CXCL8 blocked with anti-CXCL8 monoclonal antibody HuMax-IL8 reverted mesenchymalization and decreased recruitment of PMN-MDSCS in the TME, especially when combined with chemotherapy and immune-based therapy [91]. Blocking CXCR1 and CXCR2 with small molecule inhibitor SX-682 significantly abrogated CXCR2 ${ }^{+}$PMN-MDSC tumor accumulation and enhanced the efficacy of both the PD-axis immune checkpoint blockade and adoptive cell transfer of engineered T cells [92]. SX-682 can also improve the NK cell-based immunotherapy efficacy through inhibiting CXCR1/2-related PMN-MDSC trafficking in head and neck cancer models [93]. Combining SX-682 with a bifunctional anti-PD-L1 and transforming growth factor (TGF- $\beta$ ) agent bintrafusp alfa (M7824) decreased mesenchymal markers and improved antitumor activity [94]. The mechanism included inhibiting MDSC migration, enhancing $\mathrm{CD}^{+} / \mathrm{CD}^{+} \mathrm{T}$-cell infiltration, and remodeling the TME. MDSC accumulation is associated with intratumoral expression of IL1 $\beta$, IL8, CXCL5, and Mip- $1 \alpha$, and MDSCs levels were increased in the peripheral blood and tumor of patients with renal cell carcinoma. Increasing PMN-MDSC levels in the peripheral blood correlate with a higher tumor grade. A CXCR2 antagonist decreased PMN-MDSC recruitment and enhanced CD4 ${ }^{+}$and CD8 ${ }^{+}$ T-cell infiltration and the efficacy of anti-PD-1 therapy in mice bearing renal tumors [95].

NETs are extracellular web-like structures composed of granule proteins and DNA fibers. NETs can constrain and kill invasive pathogens and prevent bacterial dissemination. A recent study demonstrated that NETs may be involved in pathogenesis and tumor progression [96]. Tumor-produced CXCL8 attracts MDSC to the TME and elicits granulocytic MDSC to extrude NETs for nesting tumor cells [97]. A further study demonstrated that CXCL8 induced tumor-associated neutrophil and granulocytic MDSC extrusion of NETs, which shield tumor cells from contact with $\mathrm{CD} 8^{+} \mathrm{T}$ cells and limit the anti-PD-1 immune response to cancer [98]. Conclusive evidence showed that multiple human cancer types contain NETs, which had a positive association with CXCL8 and reduced CD8 ${ }^{+}$T-cell infiltration [99]. Tumorous CXCL8 mediates increased NETs formation in the TME, promoting colorectal cancer liver metastasis [100]. CXCL8 knockdown inhibits tumor growth in colorectal liver metastasis [101]. Cancer cells can secrete exosomes to regulate the TME. Exosomes transfer mutant KRAS to neutrophils and increase CXCL8 production and NET formation to promote CRC proliferation [102]. Nets are produced by tumor-infiltrating neutrophils involved in glioblastoma cell proliferation and invasion through stimulation of the nuclear factor kappa B (NF-kB) signaling pathway, which promoted CXCL8 secretion in glioblastomas [103]. The CXCL8/CXCR2 axis mediates the formation of NETs, which promotes proliferation and migration through TLR9 signaling in diffuse large B-cell lymphoma [104].

CXCR2 signaling is upregulated much more in neutrophil/MDSCs than in human pancreatic cancer cells and is associated with poor prognosis in patients. Inhibition of CXCR2 signaling reduces tumor metastasis, enhances sensitivity to anti-PD1 immunotherapy, and prolongs survival in mice [105]. IL-6/CXCL8 induces MDSC arginase I production to suppress $\mathrm{CD} 8^{+}$T-cell activity through the PI3K-Akt signaling pathway in gastric cancer [106]. Receptor-interacting protein kinase 3 (RIP3) knockdown promotes tumor progression and immune escape through driving MDSC recruitment by CXCR2 and decreasing interferon 
(IFN) $-\gamma^{+} \mathrm{CD}^{+} \mathrm{T}$ cells in hepatocellular carcinoma (HCC) [107]. Tumor cells induce MDSC recruitment in the bladder cancer TME through CXCL2/MIF-CXCR2 signaling, which is correlated with poor prognosis [108]. CXCL8 contributes to the recruitment of tumorassociated neutrophils that suppress $\mathrm{CD} 8^{+} \mathrm{T}$-cell activity, partly depending upon Notch signaling in ovarian cancer [109]. The expression of CXCR2 is higher in tumor stroma than tumor cells in human lung cancer and correlates with poor prognosis. Blockade of CXCR2 decreasse neutrophil infiltration in the TME and enhances antitumor T-cell activity and the antitherapeutic effects of cisplatin in lung cancer [110].

\subsubsection{Macrophages and TAMs}

TAMs constitute an important component of the TME, and can be divided into M1 macrophages and M2 macrophages. M2 macrophages can improve tumor progression and facilitate tumor immune escape. Overexpressed CXCL8 in pancreatic cancer mediates $\mathrm{CXCR} 2{ }^{+} \mathrm{CD} 8^{+}$macrophage trafficking to the TME and contributes to cancer progression and PD-1 blockade resistance. A mechanism study found that IFN- $\gamma$ suppresses the expression of CXCL8 in pancreatic cancer and inhibits TAMs migration to enhance anti-PD1 efficacy [111]. TAMs secrete CXCL8 to promote pancreatic cancer cell migration and invasion through the signal transducer and activator of transcription 3 (STAT3) pathway [112]. Neurotensin induces the secretion of CXCL8 in HCC cells. Dysfunctional activation of the neurotensin/CXCL8 pathway is associated with more EMT and worse prognosis in HCC patients [113]. HCC-derived CXCL8 enhances tumor invasion and migration by promoting M2-type TAM accumulation and EMT [114]. Macrophage-derived CXCL8 induces EMT by activating the JAK2/STAT3/Snail pathway in HCC cells [115]. CXCL8 secreted from M2 macrophages promotes prostate tumorigenesis and proliferation of prostate cancer cells in vitro [116]. TAM-derived CXCL8 enhances thyroid papillary cancer invasion and metastasis [117].

CXCL8 promotes HCC invasion and metastasis by upregulating FoxC1 expression and enhances macrophage infiltration in mice [118]. The CXCL8/STAT3 pathway plays a key role in M2 macrophage polarization and stemness of ovarian cancer stem-like cells [119]. A further study demonstrated that genistein can suppress M2 polarization of macrophages and stemness of ovarian cancer through CXCL8/STAT3 signaling [120]. CXCL8 derived from Tregs is higher than TAMs and MDSCs in malignant pleural effusion. CXCL8 further induces TGF- $\beta$ upregulation in M2 macrophages and mediates CCL22 production from TAMs, which promots an immunosuppressive TME in lung cancer [121]. CXCL8 and PAI-1 secreted from oral squamous cell carcinoma promote the differentiation of monocytes to TAMs [122]. Tumor-derived IL-6/8 impairs the function of NK cells through STAT3 signaling and enhances malignancy in primary esophageal squamous cell carcinoma [123].

\subsubsection{EMT and Stemness}

CXCL8 exerts protumor effects on the TME, such as activating EMT and enhancing stemness and therapy resistance. EMT is known to promote tumor cell motility, invasiveness, and metastasis of solid cancers. CXCL8 is an important regulator of the TME by promoting EMT and stemness in cancer cells [124]. CXCL8 secreted by tumor cells could enhance tumor progression by EMT in breast cancer cells [125].

The stemness of the breast cancer cell line MCF-7 was increased after CXCL8 stimulation in a tumorsphere-formation assay [126]. Overexpresson of CXCL8 promotes cell proliferation and migration through EMT, PI3K-Akt signaling, and E-cadherin downregulation in triple-negative breast cancer [127]. CXCL8 enhances the stemness properties of the self-renewal capability, expression of stemness-related genes, and tumorigenicity in small-cell lung cancer sphere-forming cells [128]. IL-6 and CXCL8 promote EMT and cell invasion through STAT3 signaling in oral cancer [129]. Snail is a key transcriptional repressor of E-cadherin that induces EMT and promotes tumor progression. An CXCR2 antagonist suppresses MDSC infiltration and inhibits ovarian cancer progression through the Snail/NF-kB axis [130]. Sulconazole inhibits breast cancer cell proliferation and cancer 
stem cell formation via the NF-KB/CXCL8 signaling pathway [131]. Therapeutic stress increases CXCL8 and CXCR2 expression, enhancing glioblastoma tumorigenicity, growth, and therapy resistance by inducing glioma-initiating cell formation [132]. CXCL8 enhances cancer stem cell-like properties such as sphere formation, glucose uptake, SOX2, and GLUT3 expression that promote xenograft tumor growth in lung and colon cancer cells [133]. CXCL8 enhances tumor proliferation and metastasis through the interaction between human osteosarcoma and mesenchymal stem cells in the TME [134]. Mesenchymal stem cell-derived CXCL8 promotes osteosarcoma cell anoikis resistance and pulmonary metastasis through CXCR1/Akt signaling [135]. CXCR1 gene knockdown improves the sensitivity of human osteosarcoma to cisplatin both in vivo and in vitro [136].

\subsubsection{Angiogenesis}

Angiogenesis plays a key role in tumor progression and metastasis. CXCL8 enhances angiogenesis and tumor growth through Ras/MAPK/PI3K activation [137]. CXCL8 inhibition led to an impairment of tumor vascularization and tumor death. NF- $\mathrm{KB}$ enhances the secretion of CXCL8 and VEGF to induce angiogenesis in pancreatic cancer cell lines [138]. CXCR2 significantly promotes angiogenesis, proliferation, and invasion of pancreatic cancer [139]. Pancreatic cancer cell increases CXCL8 secretion to enhance angiogenesis and acquisition of gemcitabine resistance [140]. CXCR1 promotes proliferation, migration, invasion, and metastasis in gastric cancer in vitro and in vivo [141]. CXCR1 depletion reduces angiogenic potential and decreases tumor growth in androgen-independent prostate cancer [142]. CXCL8 contributes to angiogenesis and tumor progression in glioma through the AP-1/NF-kB axis [143]. CXCL8 stimulates the proliferation and migration of vascular endohthelial cells to promote angiogenesis and tumor growth [144]. Activated endothelial cells secrete CXCL8 to promote proliferation and chemoresistance of acute myeloid leukemia [145].

CXCL8 enhances proliferation and migration through metadherin in gastric cancer in a xenografted mice model [146]. Overexpressed CXCL8 promotes intergrin $\beta 3$ upregulation and cell migration through the PI3K/Akt pathway in estrogen receptor-negative breast cancer [147] and HCC [148]. CXCL8 enhances cell migration through increasing integrin $\alpha v \beta 6$ expression in colorectal cancer [149]. Pyruvate dehydrogenase kinase 1 (PDK1) promotes ovarian cancer cell angiogenesis, invasion, and metastasis through $\alpha 5 \beta 1$ integrin and JNK/CXCL8 signaling [150]. CXCL8 and CXCL2 enhance angiogenesis through CXCR2 signaling on endothelial cells in glioblastoma [151]. Probibitin 1 decreases CXCL8 expression to inhibit tumorigenesis through NF-KB/AP-1 signaling in human liver cancers [152]. Sunitinib inhibits tumor angiogenesis through targeting VEGF or PDGF receptors in renal cell carcinoma. CXCL8 is an important contributor to sunitinib resistance, and CXCL8 blocking resensitizes renal cell carcinoma to sunitinib treatment [153].

\subsubsection{CXCL8 with Various Signaling Pathways}

Instead of the above mechanism, the CXCL8-CXCR1/2 axis have many other roles in cancer. Activated pancreatic stellate cells enhance pancreatic cancer fibrosis and progression through paracrine CXCL8 [154]. Activated hepatic stellate cells secrete CXCL8 to induce the proliferation of breast cancer cells and stimulate dormant cancer cells to grow in a 3D liver microphysiological system [155]. CXCL8 released from pancreatic cancer induces muscle atrophy to cause involuntary body weight loss or cachexia in patients [156]. Hypoxia-treated CRC tumors show increased CXCL8 expression and promote the migration, invasion, and metastasis of normoxic CRC cells [157]. Blocking the JNK/CXCL8 pathway enhances radiation-induced necroptosis and radiotherapy efficacy in colorectal cancer [158]. IL-6 and CXCL8 together promote cell density-dependent migration and the inhibition of the synergistic IL-6/CXCL8 signaling pathway reduces metastatic burden in mice [159]. CXCL8 mediates the effect of augmented FOXA1 on cell growth, invasion, and endocrine resistance in estrogen receptor-positive breast cancer [160]. Ataxia-telangiectasia mutated (ATM) protein kinase regulates CXCL8 to enhance cell migration, invasion, and 
metastasis in breast cancer [161]. Necrotic cells induce CXCL8 expression through AP$1 /$ NF- $\kappa B$ activation that promote cell migration and invasion in glioblastoma [162]. PENT plays a key role in STAT3 activation and CXCL8 secretion in tumors. CXCL8 promotes tumor progression through the STAT3 signaling pathway in head and neck squamous cell carcinoma [163].

\section{Therapeutic Targeting of the CXCL8-CXCR1/2 Axis in Cancer}

Chemokine CXCL8 activates both CXCR1 and CXCR2. All of them have been shown to be upregulated in acute or chronic inflammatory diseases including cancer. CXCR1 and CXCR2 constitute the primary mechanism for the recruitment of neutrophils and MDSCs, which could enhance tumor progression and suppress immune therapy efficacy. Blocking the CXCL8-CXCR1/2 axis with small molecules (Figure 3) or antibodies should be a promising therapeutic strategy to overcome immune suppression in the TME.<smiles>O=C(Nc1ccc([N+](=O)[O-])cc1O)Nc1ccccc1Br</smiles>

SB225002

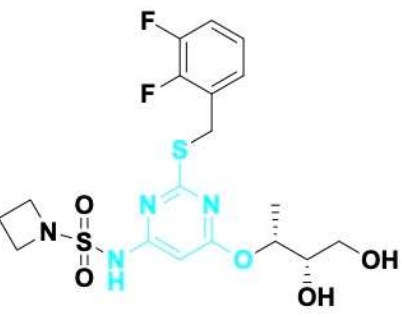

AZD5069

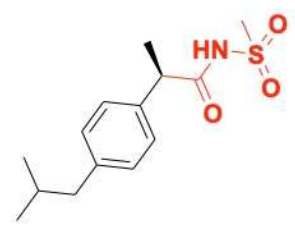

Reparixin

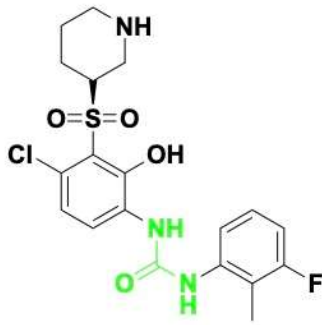

Danirixin/GSK1325756

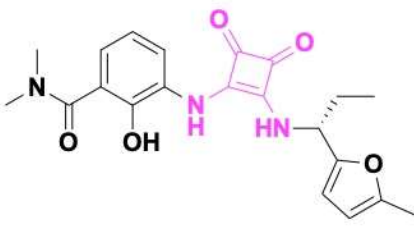

Navarixin/SCH-527123/MK-7123

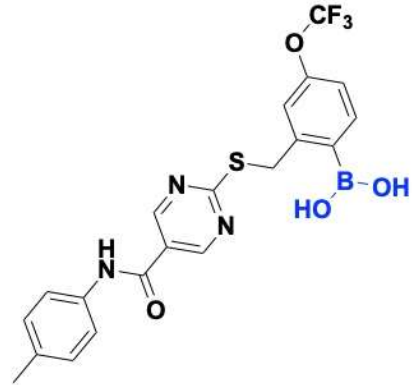

SX-682

Figure 3. Small molecule antagonists targeting CXCR1/2. Blocking CXCR1 or CXCR2 impairs immune suppressive cell recruitment and angiogenesis to enhance cancer therapy efficacy.

SB225002 was first reported as a small molecule CXCL8 inhibitor binding to CXCR2. SB225002 selectively blocked CXCL8-induced neutrophil chemotaxis and margination in rabbits [164]. Blocking CXCR2 with SB225002 has proved to inhibit tumor progression in breast cancer [165], ovarian cancer [166], acute myeloid leukemia [167], and nasopharyngeal carcinoma [168]. Reparixin is a non-competitive allosteric inhibitor of CXCR1 and CXCR2 that could inhibit polymorphonuclear cell recruitment in vivo. The activity of Reparixin on CXCR1 was 100-fold higher than on CXCR2 [169]. CXCR1 has been identified as a druggable target for breast cancer stem cells [170].

Navarixin is an orally selective, CXCR1 and CXCR2 receptor antagonist that impairs neutrophil recruitment in rodents and monkeys [171]. Navarixin decreased tumor cell proliferation and angiogenesis in a melanoma mouse model [172]. A phase II clinical trial (NCT03473925) assessed the efficacy and safty of navarixin in combination with anti-PD1 pembrolizumab in NSCLC, Castration-Resistant Prostate Cancer and Colorectal Cancer (Table 1). AZD5069 is a reversible CXCR2 antagonist that inhibits CXCL8 binding and neutrophil chemotaxis [173]. AZD5069 treatment inhibits TAM infiltration and vessel formation, increases $\mathrm{CD} 4^{+} / \mathrm{CD}^{+} \mathrm{T}$-cell infiltration, and suppresses tumor growth in advanced prostate cancer [174]. Combination therapy of AZD5069 with anti-PD1 Durvalumab (MEDI4736) was studied in patients with recurrent and/or metastatic squamous cell carcinoma of the head and neck (NCT02499328) and metastatic pancreatic ductal adenocar- 
cinoma (NCT02583477). Danirixin is also a reversible and selective antagonist of CXCR2 that may be of benefit in diseases of excess neutrophilia [175]. The clinical trial of danirixin in healthy, elderly human volunteers demonstrated that it was safe and tolerable, and no serious adverse events were reported [176,177]. A recent study showed that danirixin suppressed breast cancer migration, invasion, and metastasis mediated by CXCL8 and TAMs [178].

Table 1. Selected clinical trials targeted in CXCL8-CXCR1/2 axis.

\begin{tabular}{|c|c|c|c|c|c|c|}
\hline $\begin{array}{c}\text { Drug } \\
\text { (Manufacturer) }\end{array}$ & Target & $\begin{array}{l}\text { Therapeutic } \\
\text { Combinations }\end{array}$ & Cancer Type & Phase & $\begin{array}{l}\text { Clinical } \\
\text { Trials }\end{array}$ & $\begin{array}{c}\text { Recruitment } \\
\text { Status }\end{array}$ \\
\hline \multirow{4}{*}{$\begin{array}{l}\text { SX-682 (Syntrix } \\
\text { Biosystems, Inc.) }\end{array}$} & \multirow{4}{*}{ CXCR1/2 } & $\begin{array}{l}\text { Pembrolizumab } \\
\text { (anti-PD-1) }\end{array}$ & $\begin{array}{l}\text { Metastatic } \\
\text { Melanoma }\end{array}$ & Phase I & NCT03161431 & Recruiting \\
\hline & & $\begin{array}{l}\text { Nivolumab } \\
\text { (anti-PD-1) }\end{array}$ & $\begin{array}{l}\text { Metastatic } \\
\text { Colorectal } \\
\text { Carcinoma }\end{array}$ & Phase Ib/II & NCT04599140 & Recruiting \\
\hline & & $\begin{array}{l}\text { Nivolumab } \\
\text { (anti-PD-1) }\end{array}$ & Pancreatic Cancer & Phase I & NCT04477343 & Recruiting \\
\hline & & $\begin{array}{c}\text { Bintrafusp alfa (anti- } \\
\text { PD-L1/TGF- } \beta \text { ) } \\
\text { CV301 (cancer } \\
\text { vaccine) }\end{array}$ & $\begin{array}{l}\text { Advanced Solid } \\
\text { Tumors }\end{array}$ & Phase I & NCT04574583 & $\begin{array}{l}\text { Active, not } \\
\text { recruiting }\end{array}$ \\
\hline \multirow{2}{*}{$\begin{array}{c}\text { AZD5069 } \\
\text { (AstraZeneca) }\end{array}$} & \multirow[b]{2}{*}{ CXCR2 } & $\begin{array}{l}\text { Durvalumab } \\
\text { (anti-PD-L1) }\end{array}$ & $\begin{array}{l}\text { Advanced Solid } \\
\text { Tumors }\end{array}$ & Phase Ib/II & NCT02499328 & $\begin{array}{l}\text { Active, not } \\
\text { recruiting }\end{array}$ \\
\hline & & $\begin{array}{l}\text { Durvalumab } \\
\text { (anti-PD-L1) }\end{array}$ & $\begin{array}{c}\text { Metastatic } \\
\text { Pancreatic Ductal } \\
\text { Adenocarcinoma }\end{array}$ & Phase II & NCT02583477 & Completed \\
\hline $\begin{array}{l}\text { Navarixin (Merck } \\
\text { Sharp \& Dohme } \\
\text { Corp.) }\end{array}$ & CXCR1/2 & $\begin{array}{l}\text { Pembrolizumab } \\
\text { (anti-PD-1) }\end{array}$ & $\begin{array}{l}\text { Advanced Solid } \\
\text { Tumors }\end{array}$ & Phase II & NCT03473925 & Completed \\
\hline \multirow{6}{*}{$\begin{array}{c}\text { HuMax-IL8 } \\
\text { (Bristol-Myers } \\
\text { Squiibb) }\end{array}$} & \multirow{6}{*}{ CXCL8 } & $\begin{array}{l}\text { Nivolumab } \\
\text { (anti-PD-1) }\end{array}$ & $\begin{array}{l}\text { Head and Neck } \\
\text { Squamous Cell } \\
\text { Carcinoma }\end{array}$ & Phase II & NCT04848116 & Recruiting \\
\hline & & $\begin{array}{l}\text { Nivolumab } \\
\text { (anti-PD-1) }\end{array}$ & Prostate Cancer & Phase Ib/II & NCT03689699 & Recruiting \\
\hline & & $\begin{array}{l}\text { Nivolumab } \\
\text { (anti-PD-1) }\end{array}$ & Pancreatic Cancer & Phase II & NCT02451982 & Recruiting \\
\hline & & $\begin{array}{l}\text { Nivolumab } \\
\text { (anti-PD-1) }\end{array}$ & $\begin{array}{l}\text { Hepatocellular } \\
\text { Carcinoma }\end{array}$ & Phase II & NCT04050462 & Recruiting \\
\hline & & $\begin{array}{l}\text { Nivolumab } \\
\text { (anti-PD-1) }\end{array}$ & $\begin{array}{l}\text { Advanced } \\
\text { Cancers }\end{array}$ & Phase I/II & NCT03400332 & Recruiting \\
\hline & & $\begin{array}{l}\text { Nivolumab } \\
\text { (anti-PD-1) }\end{array}$ & $\begin{array}{l}\text { Non-small Cell } \\
\text { Lung Cancer }\end{array}$ & Phase II & NCT04123379 & Recruiting \\
\hline
\end{tabular}

SX-682 is a novel CXCR1/2 chemokine receptor boronic acid antagonist with potential anticancer activities. Orally bioavailable SX-682 enhanced NK cell activation and therapeutic efficacy by inhibiting MDSC accumulation in the TME [93]. A combination of SX-682 with anti-PD1 caused a reduction in tumor burden b7 increasing CD8+ T-cell infiltration and decreasing neutrophil accumulation in non-small cell lung cancer [179]. Treatment of tumor-bearing mice with SX682 reduced intertumoral MDSCs, increased CD8+ T-cell recruitment, and inhibited tumor growth in melanoma and breast cancer [180]. Several clinical trials were designed to assess the efficacy of SX-682 in combination with anti-PD1 Nivolumab or Pembrolizumab in metastatic melanoma, colorectal carcinoma, and pancreatic cancer (Table 1). Fully humanized neutralizing antibody ABX-IL8 inhibits angiogenesis, tumor growth, and metastasis in melanoma [181] and bladder cancer [182] through downregulation of MMP-2. HuMax-IL8(BMS-986253) is another fully human anti-CXCL8 monoclonal antibody. A phase I clinical trial of HuMax-IL8 (NCT02536469) showed no objective tumor responses, but it is safe and well tolerated [183]. Phase II clinical 
trials of HuMax-IL8 plus anti-PD1 Nivolumab are ongoing in patients with advanced solid tumors (Table 1).

Chimeric antigen receptor (CAR) T-cell therapy has shown clinical efficacy for hematological malignancies but still remains a challenge for solid tumors [184]. The major obstacles of CAR-T therapy in solid tumors are tumor heterogeneity, an immunosuppressive TME, and T-cell trafficking/infiltrating to the tumor. CXCR1/2-modified CAR-T cells enhance T-cell trafficking, persistence of T cells in the tumor, long-lasting immunologic memory, and therapy efficacy in aggressive solid tumors such as glioblastoma, ovarian, and pancreatic cancer [185].

\section{CXCL8 as a Prognosis Biomarker in Cancer Therapy}

Tumor burden (or tumor size) predicts response to immunotherapy in patients with cancer. A large TME and a small TME are characterized by different cell populations and responses to specific interventions [186]. Radiologic imaging such as computed tomographhy (CT) is the most commonly used technology for tumor burden monitoring even though it has limitations for the evaluation of the response to immunotherapy. Functional imaging techniques [187] such as positron emission tomography (PET) or electron paramagnetic resonance (EPR) can sense the TME hypoxia and visualize tissue redox status non-invasively, which assists image-guided diagnoses and efficacy evaluations of cancer therapy [188]. CXCL8 serum concentrations can accurately reflect the tumor burden of patients following antitumor therapy and have prognostic significance [189].

CXCL8 could be a serum biomarker by which to predict clinical benefit from immune checkpoint blockade in melanoma and NSCLC patients. Serum CXCL8 levels significantly decreased in responding patients treated with anti-PD1 nivolumab or pembrolizumab, which were associated with longer overall survival [190]. In gemcitabine-refractory patients with pancreatic cancer, plasma CXCL8 is a useful circulating biomarker for predicting resistance to nanoliposomal irinotecan therapy [191]. Baseline IL-6/CXCL8 can predict objective response and overall survival in patients with advanced HCC treated with sorafenib [192].

\section{Conclusions and Prospective}

As a key driver of immune suppression, CXCL8-CXCR1/2 axis blocking is a promising way to make the TME much more conductive to a therapeutic response. The present studies suggest that the CXCL8-CXCR1/2 axis has a key role in determining the types and quantity of immune-suppressive cells infiltrating cancers. The CAFs and microbiome affect the CXCL8 levels to modulate the immune homeostasis in the TME. An easily measurable prognostic biomarker is valuable for patients treated with immunotherapy since not all patients respond to immunotherapy. A large-scale retrospective analysis demonstrated that serum CXCL8 levels are associated with increased monocyte and neutrophil infiltration as well as worse prognosis in advanced cancer patients with immune checkpoint inhibitors [193]. Similar results were achieved in a large randomized study in which a high circulating CXCL8 level correlated with reduced clinical benefit of PD-L1 blockade in patients with metastatic urothelial carcinoma and metastatic renal cell carcinoma [194]. These studies suggest that plasma CXCL8 may be a prognostic biomarker in solid tumors and can be used to minimize toxicity and maximize clinical benefit. The combination of blocking the CXCL8-CXCR1/2 axis with other types of immunotherapy is a promising strategy by which to extend the durability of clinical responses in patients with cancer. Nevertheless, more clinical trials are needed to validate the CXCL8-CXCR1/2 axis in both therapeutic and prognostic roles in cancer immunotherapy.

Author Contributions: Conceptualization, Z.-J.H. and H.C.; writing, Z.-J.H., Y.-B.L., L.-X.Y. and H.-J.C.; review and editing, H.C.; software, X.L. All authors have read and agreed to the published version of the manuscript. 
Funding: This research was funded by the Natural Science Foundation of Gansu Province (No. 21JR1RA165), COVID-19 prevention and control technology research project of Lanzhou City (No. 2020-XG-58), Science and technology project of Chengguan District of Lanzhou City (No. 2019RCCX0034), Cuiying Scientific Training Program for Undergraduates of Lanzhou University Second Hospital (No. CYXZ2019-07 and CYXZ2019-15).

Acknowledgments: We are thankful to Lanzhou University Second Hospital and the library of Lanzhou University for their literature and database support. We are also acknowledging the Government of Lanzhou and Gansu Province for their financial assistance.

Conflicts of Interest: The authors declare no conflict of interest.

\section{References}

1. Quail, D.F.; Joyce, J.A. Microenvironmental regulation of tumor progression and metastasis. Nat. Med. 2013, $19,1423-1437$. [CrossRef] [PubMed]

2. Hernández-Camarero, P.; López-Ruiz, E.; Marchal, J.A.; Perán, M. Cancer: A mirrored room between tumor bulk and tumor microenvironment. J. Exp. Clin. Cancer Res. 2021, 40, 217. [CrossRef] [PubMed]

3. Briukhovetska, D.; Dörr, J.; Endres, S.; Libby, P.; Dinarello, C.A.; Kobold, S. Interleukins in cancer: From biology to therapy. Nat. Rev. Cancer 2021, 21, 481-499. [CrossRef]

4. Ha, H.; Debnath, B.; Neamati, N. Role of the CXCL8-CXCR1/2 Axis in Cancer and Inflammatory Diseases. Theranostics 2017, 7, 1543-1588. [CrossRef] [PubMed]

5. Waldman, A.D.; Fritz, J.M.; Lenardo, M.J. A guide to cancer immunotherapy: From T cell basic science to clinical practice. Nat. Rev. Immunol. 2020, 20, 651-668. [CrossRef]

6. Lu, Z.; Peng, Z.; Liu, C.; Wang, Z.; Wang, Y.; Jiao, X.; Li, J.; Shen, L. Current Status and Future Perspective of Immunotherapy in Gastrointestinal Cancers. Innovation 2020, 1, 100041. [CrossRef]

7. Kalbasi, A.; Ribas, A. Tumour-intrinsic resistance to immune checkpoint blockade. Nat. Rev. Immunol. 2020, 20, 25-39. [CrossRef]

8. Rahimi Kalateh Shah Mohammad, G.; Ghahremanloo, A.; Soltani, A.; Fathi, E.; Hashemy, S.I. Cytokines as potential combination agents with PD-1/PD-L1 blockade for cancer treatment. J. Cell. Physiol. 2020, 235, 5449-5460. [CrossRef] [PubMed]

9. Kaemmerer, E.; Loessner, D.; Avery, V.M. Addressing the tumour microenvironment in early drug discovery: A strategy to overcome drug resistance and identify novel targets for cancer therapy. Drug Discov. Today 2021, 26, 663-676. [CrossRef]

10. Zhang, P.; Meng, J.; Li, Y.; Yang, C.; Hou, Y.; Tang, W.; McHugh, K.J.; Jing, L. Nanotechnology-enhanced immunotherapy for metastatic cancer. Innovation 2021, 2, 100174. [CrossRef] [PubMed]

11. Li, H.; Zhou, L.; Zhou, J.; Li, Q.; Ji, Q. Underlying mechanisms and drug intervention strategies for the tumour microenvironment. J. Exp. Clin. Cancer Res. 2021, 40, 97. [CrossRef]

12. Reinfeld, B.I.; Madden, M.Z.; Wolf, M.M.; Chytil, A.; Bader, J.E.; Patterson, A.R.; Sugiura, A.; Cohen, A.S.; Ali, A.; Do, B.T.; et al. Cell-programmed nutrient partitioning in the tumour microenvironment. Nature 2021, 593, 282-288. [CrossRef] [PubMed]

13. Jin, M.Z.; Jin, W.L. The updated landscape of tumor microenvironment and drug repurposing. Signal Transduct. Target. Ther. 2020, 5, 166. [CrossRef] [PubMed]

14. Rieckmann, J.C.; Geiger, R.; Hornburg, D.; Wolf, T.; Kveler, K.; Jarrossay, D.; Sallusto, F.; Shen-Orr, S.S.; Lanzavecchia, A.; Mann, M.; et al. Social network architecture of human immune cells unveiled by quantitative proteomics. Nat. Immunol. 2017, 18, 583-593. [CrossRef] [PubMed]

15. Hirata, E.; Sahai, E. Tumor Microenvironment and Differential Responses to Therapy. Cold Spring Harb. Perspect Med. 2017, 7, a026781. [CrossRef] [PubMed]

16. Turley, S.J.; Cremasco, V.; Astarita, J.L. Immunological hallmarks of stromal cells in the tumour microenvironment. Nat. Rev. Immunol. 2015, 15, 669-682. [CrossRef]

17. Koustoulidou, S.; Hoorens, M.W.H.; Dalm, S.U.; Mahajan, S.; Debets, R.; Seimbille, Y.; de Jong, M. Cancer-Associated Fibroblasts as Players in Cancer Development and Progression and Their Role in Targeted Radionuclide Imaging and Therapy. Cancers 2021, 13, 1100. [CrossRef]

18. Galon, J.; Bruni, D. Approaches to treat immune hot, altered and cold tumours with combination immunotherapies. Nat. Rev. Drug Discov. 2019, 18, 197-218. [CrossRef]

19. Binnewies, M.; Roberts, E.W.; Kersten, K.; Chan, V.; Fearon, D.F.; Merad, M.; Coussens, L.M.; Gabrilovich, D.I.; Ostrand-Rosenberg, S.; Hedrick, C.C.; et al. Understanding the tumor immune microenvironment (TIME) for effective therapy. Nat. Med. 2018, 24, 541-550. [CrossRef]

20. Nagarsheth, N.; Wicha, M.S.; Zou, W. Chemokines in the cancer microenvironment and their relevance in cancer immunotherapy. Nat. Rev. Immunol. 2017, 17, 559-572. [CrossRef]

21. Liu, Q.; Li, A.; Tian, Y.; Wu, J.D.; Liu, Y.; Li, T.; Chen, Y.; Han, X.; Wu, K. The CXCL8-CXCR1/2 pathways in cancer. Cytokine Growth Factor Rev. 2016, 31, 61-71. [CrossRef] [PubMed]

22. Alfaro, C.; Sanmamed, M.F.; Rodríguez-Ruiz, M.E.; Teijeira, Á.; Oñate, C.; González, Á.; Ponz, M.; Schalper, K.A.; Pérez-Gracia, J.L.; Melero, I. Interleukin-8 in cancer pathogenesis, treatment and follow-up. Cancer Treat. Rev. 2017, 60, 24-31. [CrossRef] 
23. Gonzalez-Aparicio, M.; Alfaro, C. Significance of the IL-8 pathway for immunotherapy. Hum. Vaccin. Immunother. 2020, 16, 2312-2317. [CrossRef]

24. Fousek, K.; Horn, L.A.; Palena, C. Interleukin-8: A chemokine at the intersection of cancer plasticity, angiogenesis, and immune suppression. Pharmacol. Ther. 2021, 219, 107692. [CrossRef] [PubMed]

25. David, J.M.; Dominguez, C.; Hamilton, D.H.; Palena, C. The IL-8/IL-8R Axis: A Double Agent in Tumor Immune Resistance. Vaccines 2016, 4, 22. [CrossRef] [PubMed]

26. Chen, X.; Song, E. Turning foes to friends: Targeting cancer-associated fibroblasts. Nat. Rev. Drug Discov. 2019, 18, 99-115. [CrossRef]

27. Öhlund, D.; Elyada, E.; Tuveson, D. Fibroblast heterogeneity in the cancer wound. J. Exp. Med. 2014, 211, 1503-1523. [CrossRef] [PubMed]

28. Wu, F.; Yang, J.; Liu, J.; Wang, Y.; Mu, J.; Zeng, Q.; Deng, S.; Zhou, H. Signaling pathways in cancer-associated fibroblasts and targeted therapy for cancer. Signal Transduct. Target. Ther. 2021, 6, 218. [CrossRef]

29. Yoshida, G.J. Regulation of heterogeneous cancer-associated fibroblasts: The molecular pathology of activated signaling pathways. J. Exp. Clin. Cancer Res. 2020, 39, 112. [CrossRef]

30. Chen, Y.; McAndrews, K.M.; Kalluri, R. Clinical and therapeutic relevance of cancer-associated fibroblasts. Nat. Rev. Clin. Oncol. 2021, 18, 792-804. [CrossRef]

31. Barrett, R.L.; Puré, E. Cancer-associated fibroblasts and their influence on tumor immunity and immunotherapy. Elife 2020, 9 , e57243. [CrossRef] [PubMed]

32. Arina, A.; Idel, C.; Hyjek, E.M.; Alegre, M.L.; Wang, Y.; Bindokas, V.P.; Weichselbaum, R.R.; Schreiber, H. Tumor-associated fibroblasts predominantly come from local and not circulating precursors. Proc. Natl. Acad. Sci. USA 2016, 113, 7551-7556. [CrossRef] [PubMed]

33. Tsuchida, T.; Friedman, S.L. Mechanisms of hepatic stellate cell activation. Nat. Rev. Gastroenterol. Hepatol. 2017, 14, 397-411. [CrossRef] [PubMed]

34. Thomas, D.; Radhakrishnan, P. Tumor-stromal crosstalk in pancreatic cancer and tissue fibrosis. Mol. Cancer 2019, 18, 14 [CrossRef] [PubMed]

35. Bochet, L.; Lehuédé, C.; Dauvillier, S.; Wang, Y.Y.; Dirat, B.; Laurent, V.; Dray, C.; Guiet, R.; Maridonneau-Parini, I.; Le Gonidec, S.; et al. Adipocyte-derived fibroblasts promote tumor progression and contribute to the desmoplastic reaction in breast cancer. Cancer Res. 2013, 73, 5657-5668. [CrossRef]

36. Zeisberg, E.M.; Potenta, S.; Xie, L.; Zeisberg, M.; Kalluri, R. Discovery of endothelial to mesenchymal transition as a source for carcinoma-associated fibroblasts. Cancer Res. 2007, 67, 10123-10128. [CrossRef]

37. Willis, B.C.; duBois, R.M.; Borok, Z. Epithelial origin of myofibroblasts during fibrosis in the lung. Proc. Am. Thorac Soc. 2006, 3 , 377-382. [CrossRef]

38. Quante, M.; Tu, S.P.; Tomita, H.; Gonda, T.; Wang, S.S.; Takashi, S.; Baik, G.H.; Shibata, W.; Diprete, B.; Betz, K.S.; et al. Bone marrow-derived myofibroblasts contribute to the mesenchymal stem cell niche and promote tumor growth. Cancer Cell 2011, 19, 257-272. [CrossRef]

39. Spaeth, E.L.; Dembinski, J.L.; Sasser, A.K.; Watson, K.; Klopp, A.; Hall, B.; Andreeff, M.; Marini, F. Mesenchymal stem cell transition to tumor-associated fibroblasts contributes to fibrovascular network expansion and tumor progression. PLoS ONE 2009, 4, e4992. [CrossRef] [PubMed]

40. Kalluri, R. The biology and function of fibroblasts in cancer. Nat. Rev. Cancer 2016, 16, 582-598. [CrossRef]

41. Helms, E.; Onate, M.K.; Sherman, M.H. Fibroblast Heterogeneity in the Pancreatic Tumor Microenvironment. Cancer Discov. 2020, 10, 648-656. [CrossRef]

42. Zeltz, C.; Primac, I.; Erusappan, P.; Alam, J.; Noel, A.; Gullberg, D. Cancer-associated fibroblasts in desmoplastic tumors: Emerging role of integrins. Semin. Cancer Biol. 2020, 62, 166-181. [CrossRef]

43. Sahai, E.; Astsaturov, I.; Cukierman, E.; DeNardo, D.G.; Egeblad, M.; Evans, R.M.; Fearon, D.; Greten, F.R.; Hingorani, S.R.; Hunter, T.; et al. A framework for advancing our understanding of cancer-associated fibroblasts. Nat. Rev. Cancer 2020, 20, 174-186. [CrossRef]

44. Hutton, C.; Heider, F.; Blanco-Gomez, A.; Banyard, A.; Kononov, A.; Zhang, X.; Karim, S.; Paulus-Hock, V.; Watt, D.; Steele, N.; et al. Single-cell analysis defines a pancreatic fibroblast lineage that supports antitumor immunity. Cancer Cell 2021, 39, 1227-1244.e20. [CrossRef]

45. Mishra, P.; Banerjee, D.; Ben-Baruch, A. Chemokines at the crossroads of tumor-fibroblast interactions that promote malignancy. J. Leukoc. Biol. 2011, 89, 31-39. [CrossRef]

46. Zhang, R.; Qi, F.; Zhao, F.; Li, G.; Shao, S.; Zhang, X.; Yuan, L.; Feng, Y. Cancer-associated fibroblasts enhance tumor-associated macrophages enrichment and suppress NK cells function in colorectal cancer. Cell Death Dis. 2019, 10, 273. [CrossRef] [PubMed]

47. Zhai, J.; Shen, J.; Xie, G.; Wu, J.; He, M.; Gao, L.; Zhang, Y.; Yao, X.; Shen, L. Cancer-associated fibroblasts-derived IL-8 mediates resistance to cisplatin in human gastric cancer. Cancer Lett. 2019, 454, 37-43. [CrossRef] [PubMed]

48. Kumar, V.; Donthireddy, L.; Marvel, D.; Condamine, T.; Wang, F.; Lavilla-Alonso, S.; Hashimoto, A.; Vonteddu, P.; Behera, R.; Goins, M.A.; et al. Cancer-Associated Fibroblasts Neutralize the Antitumor Effect of CSF1 Receptor Blockade by Inducing PMN-MDSC Infiltration of Tumors. Cancer Cell 2017, 32, 654-668.e5. [CrossRef] 
49. Rubinstein-Achiasaf, L.; Morein, D.; Ben-Yaakov, H.; Liubomirski, Y.; Meshel, T.; Elbaz, E.; Dorot, O.; Pichinuk, E.; Gershovits, M.; Weil, M.; et al. Persistent Inflammatory Stimulation Drives the Conversion of MSCs to Inflammatory CAFs That Promote Pro-Metastatic Characteristics in Breast Cancer Cells. Cancers 2021, 13, 1472. [CrossRef] [PubMed]

50. Ji, Z.; Tian, W.; Gao, W.; Zang, R.; Wang, H.; Yang, G. Cancer-Associated Fibroblast-Derived Interleukin-8 Promotes Ovarian Cancer Cell Stemness and Malignancy Through the Notch3-Mediated Signaling. Front. Cell Dev. Biol. 2021, 9, 684505. [CrossRef]

51. Naito, Y.; Yamamoto, Y.; Sakamoto, N.; Shimomura, I.; Kogure, A.; Kumazaki, M.; Yokoi, A.; Yashiro, M.; Kiyono, T.; Yanagihara, K.; et al. Cancer extracellular vesicles contribute to stromal heterogeneity by inducing chemokines in cancer-associated fibroblasts. Oncogene 2019, 38, 5566-5579. [CrossRef]

52. New, J.; Arnold, L.; Ananth, M.; Alvi, S.; Thornton, M.; Werner, L.; Tawfik, O.; Dai, H.; Shnayder, Y.; Kakarala, K.; et al. Secretory Autophagy in Cancer-Associated Fibroblasts Promotes Head and Neck Cancer Progression and Offers a Novel Therapeutic Target. Cancer Res. 2017, 77, 6679-6691. [CrossRef]

53. Katanov, C.; Lerrer, S.; Liubomirski, Y.; Leider-Trejo, L.; Meshel, T.; Bar, J.; Feniger-Barish, R.; Kamer, I.; Soria-Artzi, G.; Kahani, H.; et al. Regulation of the inflammatory profile of stromal cells in human breast cancer: Prominent roles for TNF- $\alpha$ and the NF-кB pathway. Stem Cell Res. Ther. 2015, 6, 87. [CrossRef] [PubMed]

54. Liubomirski, Y.; Lerrer, S.; Meshel, T.; Morein, D.; Rubinstein-Achiasaf, L.; Sprinzak, D.; Wiemann, S.; Körner, C.; Ehrlich, M.; Ben-Baruch, A. Notch-Mediated Tumor-Stroma-Inflammation Networks Promote Invasive Properties and CXCL8 Expression in Triple-Negative Breast Cancer. Front. Immunol. 2019, 10, 804. [CrossRef]

55. Cioni, B.; Nevedomskaya, E.; Melis, M.H.M.; van Burgsteden, J.; Stelloo, S.; Hodel, E.; Spinozzi, D.; de Jong, J.; van der Poel, H.; de Boer, J.P.; et al. Loss of androgen receptor signaling in prostate cancer-associated fibroblasts (CAFs) promotes CCL2- and CXCL8-mediated cancer cell migration. Mol. Oncol. 2018, 12, 1308-1323. [CrossRef] [PubMed]

56. Awaji, M.; Saxena, S.; Wu, L.; Prajapati, D.R.; Purohit, A.; Varney, M.L.; Kumar, S.; Rachagani, S.; Ly, Q.P.; Jain, M.; et al. CXCR2 signaling promotes secretory cancer-associated fibroblasts in pancreatic ductal adenocarcinoma. FASEB J. 2020, 34, 9405-9418. [CrossRef] [PubMed]

57. Sonnenberg, M.; van der Kuip, H.; Haubeis, S.; Fritz, P.; Schroth, W.; Friedel, G.; Simon, W.; Mürdter, T.E.; Aulitzky, W.E. Highly variable response to cytotoxic chemotherapy in carcinoma-associated fibroblasts (CAFs) from lung and breast. BMC Cancer $\mathbf{2 0 0 8}$ 8, 364. [CrossRef] [PubMed]

58. Chan, T.S.; Hsu, C.C.; Pai, V.C.; Liao, W.Y.; Huang, S.S.; Tan, K.T.; Yen, C.J.; Hsu, S.C.; Chen, W.Y.; Shan, Y.S.; et al. Metronomic chemotherapy prevents therapy-induced stromal activation and induction of tumor-initiating cells. J. Exp. Med. 2016, 213, 2967-2988. [CrossRef]

59. Wang, W.; Tang, Y.A.; Xiao, Q.; Lee, W.C.; Cheng, B.; Niu, Z.; Oguz, G.; Feng, M.; Lee, P.L.; Li, B.; et al. Stromal induction of BRD4 phosphorylation Results in Chromatin Remodeling and BET inhibitor Resistance in Colorectal Cancer. Nat. Commun. 2021, 12, 4441. [CrossRef]

60. Jobe, N.P.; Rösel, D.; Dvořánková, B.; Kodet, O.; Lacina, L.; Mateu, R.; Smetana, K.; Brábek, J. Simultaneous blocking of IL-6 and IL-8 is sufficient to fully inhibit CAF-induced human melanoma cell invasiveness. Histochem. Cell Biol. 2016, 146, $205-217$. [CrossRef]

61. Orjalo, A.V.; Bhaumik, D.; Gengler, B.K.; Scott, G.K.; Campisi, J. Cell surface-bound IL-1alpha is an upstream regulator of the senescence-associated IL-6/IL-8 cytokine network. Proc. Natl. Acad. Sci. USA 2009, 106, 17031-17036. [CrossRef]

62. Wang, T.; Notta, F.; Navab, R.; Joseph, J.; Ibrahimov, E.; Xu, J.; Zhu, C.Q.; Borgida, A.; Gallinger, S.; Tsao, M.S. Senescent Carcinoma-Associated Fibroblasts Upregulate IL8 to Enhance Prometastatic Phenotypes. Mol. Cancer Res. 2017, 15, 3-14. [CrossRef] [PubMed]

63. Su, S.; Chen, J.; Yao, H.; Liu, J.; Yu, S.; Lao, L.; Wang, M.; Luo, M.; Xing, Y.; Chen, F.; et al. CD10(+)GPR77(+) Cancer-Associated Fibroblasts Promote Cancer Formation and Chemoresistance by Sustaining Cancer Stemness. Cell 2018, 172, 841-856.e16. [CrossRef] [PubMed]

64. Helmink, B.A.; Khan, M.A.W.; Hermann, A.; Gopalakrishnan, V.; Wargo, J.A. The microbiome, cancer, and cancer therapy. Nat. Med. 2019, 25, 377-388. [CrossRef]

65. Sethi, V.; Kurtom, S.; Tarique, M.; Lavania, S.; Malchiodi, Z.; Hellmund, L.; Zhang, L.; Sharma, U.; Giri, B.; Garg, B.; et al. Gut Microbiota Promotes Tumor Growth in Mice by Modulating Immune Response. Gastroenterology 2018, 155, 33-37.e6. [CrossRef] [PubMed]

66. Mehrian-Shai, R.; Reichardt, J.K.V.; Harris, C.C.; Toren, A. The Gut-Brain Axis, Paving the Way to Brain Cancer. Trends Cancer 2019, 5, 200-207. [CrossRef] [PubMed]

67. Schluter, J.; Peled, J.U.; Taylor, B.P.; Markey, K.A.; Smith, M.; Taur, Y.; Niehus, R.; Staffas, A.; Dai, A.; Fontana, E.; et al. The gut microbiota is associated with immune cell dynamics in humans. Nature 2020, 588, 303-307. [CrossRef]

68. Derosa, L.; Hellmann, M.D.; Spaziano, M.; Halpenny, D.; Fidelle, M.; Rizvi, H.; Long, N.; Plodkowski, A.J.; Arbour, K.C.; Chaft, J.E.; et al. Negative association of antibiotics on clinical activity of immune checkpoint inhibitors in patients with advanced renal cell and non-small-cell lung cancer. Ann. Oncol. 2018, 29, 1437-1444. [CrossRef] [PubMed]

69. Maier, L.; Pruteanu, M.; Kuhn, M.; Zeller, G.; Telzerow, A.; Anderson, E.E.; Brochado, A.R.; Fernandez, K.C.; Dose, H.; Mori, H.; et al. Extensive impact of non-antibiotic drugs on human gut bacteria. Nature 2018, 555, 623-628. [CrossRef]

70. Bajaj, J.S. Alcohol, liver disease and the gut microbiota. Nat. Rev. Gastroenterol. Hepatol. 2019, 16, 235-246. [CrossRef] 
71. Desai, M.S.; Seekatz, A.M.; Koropatkin, N.M.; Kamada, N.; Hickey, C.A.; Wolter, M.; Pudlo, N.A.; Kitamoto, S.; Terrapon, N.; Muller, A.; et al. A Dietary Fiber-Deprived Gut Microbiota Degrades the Colonic Mucus Barrier and Enhances Pathogen Susceptibility. Cell 2016, 167, 1339-1353.e21. [CrossRef]

72. Rai, A.K.; Panda, M.; Das, A.K.; Rahman, T.; Das, R.; Das, K.; Sarma, A.; Kataki, A.C.; Chattopadhyay, I. Dysbiosis of salivary microbiome and cytokines influence oral squamous cell carcinoma through inflammation. Arch. Microbiol. 2021, 203, 137-152. [CrossRef]

73. Watanabe, K.; Gilchrist, C.A.; Uddin, M.J.; Burgess, S.L.; Abhyankar, M.M.; Moonah, S.N.; Noor, Z.; Donowitz, J.R.; Schneider, B.N.; Arju, T.; et al. Microbiome-mediated neutrophil recruitment via CXCR2 and protection from amebic colitis. PLoS Pathog. 2017, 13, e1006513. [CrossRef]

74. Jenkins, S.V.; Robeson, M.S., 2nd; Griffin, R.J.; Quick, C.M.; Siegel, E.R.; Cannon, M.J.; Vang, K.B.; Dings, R.P.M. Gastrointestinal Tract Dysbiosis Enhances Distal Tumor Progression through Suppression of Leukocyte Trafficking. Cancer Res. 2019, 79, 5999-6009. [CrossRef] [PubMed]

75. Münch, N.S.; Fang, H.Y.; Ingermann, J.; Maurer, H.C.; Anand, A.; Kellner, V.; Sahm, V.; Wiethaler, M.; Baumeister, T.; Wein, F.; et al. High-Fat Diet Accelerates Carcinogenesis in a Mouse Model of Barrett's Esophagus via Interleukin 8 and Alterations to the Gut Microbiome. Gastroenterology 2019, 157, 492-506.e2. [CrossRef] [PubMed]

76. Zhang, Q.; Ma, C.; Duan, Y.; Heinrich, B.; Rosato, U.; Diggs, L.P.; Ma, L.; Roy, S.; Fu, Q.; Brown, Z.J.; et al. Gut Microbiome Directs Hepatocytes to Recruit MDSCs and Promote Cholangiocarcinoma. Cancer Discov. 2021, 11, 1248-1267. [CrossRef] [PubMed]

77. Suez, J.; Zmora, N.; Segal, E.; Elinav, E. The pros, cons, and many unknowns of probiotics. Nat. Med. 2019, 25, 716-729. [CrossRef]

78. Chen, D.; Wu, J.; Jin, D.; Wang, B.; Cao, H. Fecal microbiota transplantation in cancer management: Current status and perspectives. Int. J. Cancer 2019, 145, 2021-2031. [CrossRef]

79. Zheng, D.W.; Dong, X.; Pan, P.; Chen, K.W.; Fan, J.X.; Cheng, S.X.; Zhang, X.Z. Phage-guided modulation of the gut microbiota of mouse models of colorectal cancer augments their responses to chemotherapy. Nat. Biomed. Eng. 2019, 3, 717-728. [CrossRef] [PubMed]

80. Hibberd, A.A.; Lyra, A.; Ouwehand, A.C.; Rolny, P.; Lindegren, H.; Cedgård, L.; Wettergren, Y. Intestinal microbiota is altered in patients with colon cancer and modified by probiotic intervention. BMJ Open Gastroenterol. 2017, 4, e000145. [CrossRef]

81. Song, H.; Wang, W.; Shen, B.; Jia, H.; Hou, Z.; Chen, P.; Sun, Y. Pretreatment with probiotic Bifico ameliorates colitis-associated cancer in mice: Transcriptome and gut flora profiling. Cancer Sci. 2018, 109, 666-677. [CrossRef]

82. Baruch, E.N.; Youngster, I.; Ben-Betzalel, G.; Ortenberg, R.; Lahat, A.; Katz, L.; Adler, K.; Dick-Necula, D.; Raskin, S.; Bloch, N.; et al. Fecal microbiota transplant promotes response in immunotherapy-refractory melanoma patients. Science 2021, 371, 602-609. [CrossRef]

83. Davar, D.; Dzutsev, A.K.; McCulloch, J.A.; Rodrigues, R.R.; Chauvin, J.M.; Morrison, R.M.; Deblasio, R.N.; Menna, C.; Ding, Q.; Pagliano, O.; et al. Fecal microbiota transplant overcomes resistance to anti-PD-1 therapy in melanoma patients. Science 2021, 371, 595-602. [CrossRef]

84. Otte, J.M.; Cario, E.; Podolsky, D.K. Mechanisms of cross hyporesponsiveness to Toll-like receptor bacterial ligands in intestinal epithelial cells. Gastroenterology 2004, 126, 1054-1070. [CrossRef] [PubMed]

85. Wong-Rolle, A.; Wei, H.K.; Zhao, C.; Jin, C. Unexpected guests in the tumor microenvironment: Microbiome in cancer. Protein Cell 2021, 12, 426-435. [CrossRef] [PubMed]

86. Jin, C.; Lagoudas, G.K.; Zhao, C.; Bullman, S.; Bhutkar, A.; Hu, B.; Ameh, S.; Sandel, D.; Liang, X.S.; Mazzilli, S.; et al. Commensal Microbiota Promote Lung Cancer Development via $\gamma \delta$ T Cells. Cell 2019, 176, 998-1013.e16. [CrossRef]

87. Vesty, A.; Gear, K.; Biswas, K.; Radcliff, F.J.; Taylor, M.W.; Douglas, R.G. Microbial and inflammatory-based salivary biomarkers of head and neck squamous cell carcinoma. Clin. Exp. Dent. Res. 2018, 4, 255-262. [CrossRef] [PubMed]

88. Alfaro, C.; Suárez, N.; Martínez-Forero, I.; Palazón, A.; Rouzaut, A.; Solano, S.; Feijoo, E.; Gúrpide, A.; Bolaños, E.; Erro, L.; et al. Carcinoma-derived interleukin-8 disorients dendritic cell migration without impairing T-cell stimulation. PLoS ONE 2011, 6 , e17922. [CrossRef]

89. Rapoport, B.L.; Steel, H.C.; Theron, A.J.; Smit, T.; Anderson, R. Role of the Neutrophil in the Pathogenesis of Advanced Cancer and Impaired Responsiveness to Therapy. Molecules 2020, 25, 1618. [CrossRef] [PubMed]

90. Highfill, S.L.; Cui, Y.; Giles, A.J.; Smith, J.P.; Zhang, H.; Morse, E.; Kaplan, R.N.; Mackall, C.L. Disruption of CXCR2-mediated MDSC tumor trafficking enhances anti-PD1 efficacy. Sci. Transl. Med. 2014, 6, 237ra67. [CrossRef]

91. Dominguez, C.; McCampbell, K.K.; David, J.M.; Palena, C. Neutralization of IL-8 decreases tumor PMN-MDSCs and reduces mesenchymalization of claudin-low triple-negative breast cancer. JCI Insight 2017, 2, e94296. [CrossRef] [PubMed]

92. Sun, L.; Clavijo, P.E.; Robbins, Y.; Patel, P.; Friedman, J.; Greene, S.; Das, R.; Silvin, C.; Van Waes, C.; Horn, L.A.; et al. Inhibiting myeloid-derived suppressor cell trafficking enhances T cell immunotherapy. JCI Insight 2019, 4, e126853. [CrossRef] [PubMed]

93. Greene, S.; Robbins, Y.; Mydlarz, W.K.; Huynh, A.P.; Schmitt, N.C.; Friedman, J.; Horn, L.A.; Palena, C.; Schlom, J.; Maeda, D.Y.; et al. Inhibition of MDSC Trafficking with SX-682, a CXCR1/2 Inhibitor, Enhances NK-Cell Immunotherapy in Head and Neck Cancer Models. Clin. Cancer Res. 2020, 26, 1420-1431. [CrossRef]

94. Horn, L.A.; Riskin, J.; Hempel, H.A.; Fousek, K.; Lind, H.; Hamilton, D.H.; McCampbell, K.K.; Maeda, D.Y.; Zebala, J.A.; Su, Z.; et al. Simultaneous inhibition of CXCR1/2, TGF- $\beta$, and PD-L1 remodels the tumor and its microenvironment to drive antitumor immunity. J. Immunother. Cancer 2020, 8, e000326. [CrossRef] [PubMed] 
95. Najjar, Y.G.; Rayman, P.; Jia, X.; Pavicic, P.G., Jr.; Rini, B.I.; Tannenbaum, C.; Ko, J.; Haywood, S.; Cohen, P.; Hamilton, T.; et al. Myeloid-Derived Suppressor Cell Subset Accumulation in Renal Cell Carcinoma Parenchyma Is Associated with Intratumoral Expression of IL1 $\beta$, IL8, CXCL5, and Mip-1 $\alpha$. Clin. Cancer Res. 2017, 23, 2346-2355. [CrossRef]

96. Shao, B.Z.; Yao, Y.; Li, J.P.; Chai, N.L.; Linghu, E.Q. The Role of Neutrophil Extracellular Traps in Cancer. Front. Oncol. 2021, 11, 714357. [CrossRef]

97. Alfaro, C.; Teijeira, A.; Oñate, C.; Pérez, G.; Sanmamed, M.F.; Andueza, M.P.; Alignani, D.; Labiano, S.; Azpilikueta, A.; Rodriguez-Paulete, A.; et al. Tumor-Produced Interleukin-8 Attracts Human Myeloid-Derived Suppressor Cells and Elicits Extrusion of Neutrophil Extracellular Traps (NETs). Clin. Cancer Res. 2016, 22, 3924-3936. [CrossRef]

98. Teijeira, Á.; Garasa, S.; Gato, M.; Alfaro, C.; Migueliz, I.; Cirella, A.; de Andrea, C.; Ochoa, M.C.; Otano, I.; Etxeberria, I.; et al. CXCR1 and CXCR2 Chemokine Receptor Agonists Produced by Tumors Induce Neutrophil Extracellular Traps that Interfere with Immune Cytotoxicity. Immunity 2020, 52, 856-871.e8. [CrossRef]

99. de Andrea, C.E.; Ochoa, M.C.; Villalba-Esparza, M.; Teijeira, Á.; Schalper, K.A.; Abengozar-Muela, M.; Eguren-Santamaría, I.; Sainz, C.; Sánchez-Gregorio, S.; Garasa, S.; et al. Heterogenous presence of neutrophil extracellular traps in human solid tumours is partially dependent on IL-8. J. Pathol. 2021, 255, 190-201. [CrossRef]

100. Yang, L.; Liu, L.; Zhang, R.; Hong, J.; Wang, Y.; Wang, J.; Zuo, J.; Zhang, J.; Chen, J.; Hao, H. IL-8 mediates a positive loop connecting increased neutrophil extracellular traps (NETs) and colorectal cancer liver metastasis. J. Cancer 2020, 11, 4384-4396. [CrossRef] [PubMed]

101. Kumar, A.; Cherukumilli, M.; Mahmoudpour, S.H.; Brand, K.; Bandapalli, O.R. ShRNA-mediated knock-down of CXCL8 inhibits tumor growth in colorectal liver metastasis. Biochem. Biophys. Res. Commun. 2018, 500, 731-737. [CrossRef] [PubMed]

102. Shang, A.; Gu, C.; Zhou, C.; Yang, Y.; Chen, C.; Zeng, B.; Wu, J.; Lu, W.; Wang, W.; Sun, Z.; et al. Exosomal KRAS mutation promotes the formation of tumor-associated neutrophil extracellular traps and causes deterioration of colorectal cancer by inducing IL-8 expression. Cell Commun. Signal. 2020, 18, 52. [CrossRef]

103. Zha, C.; Meng, X.; Li, L.; Mi, S.; Qian, D.; Li, Z.; Wu, P.; Hu, S.; Zhao, S.; Cai, J.; et al. Neutrophil extracellular traps mediate the crosstalk between glioma progression and the tumor microenvironment via the HMGB1/RAGE/IL-8 axis. Cancer Biol Med. 2020, 17, 154-168. [CrossRef] [PubMed]

104. Nie, M.; Yang, L.; Bi, X.; Wang, Y.; Sun, P.; Yang, H.; Liu, P.; Li, Z.; Xia, Y.; Jiang, W. Neutrophil Extracellular Traps Induced by IL8 Promote Diffuse Large B-cell Lymphoma Progression via the TLR9 Signaling. Clin. Cancer Res. 2019, 25, 1867-1879. [CrossRef] [PubMed]

105. Steele, C.W.; Karim, S.A.; Leach, J.D.G.; Bailey, P.; Upstill-Goddard, R.; Rishi, L.; Foth, M.; Bryson, S.; McDaid, K.; Wilson, Z.; et al. CXCR2 Inhibition Profoundly Suppresses Metastases and Augments Immunotherapy in Pancreatic Ductal Adenocarcinoma. Cancer Cell 2016, 29, 832-845. [CrossRef] [PubMed]

106. Mao, F.Y.; Zhao, Y.L.; Lv, Y.P.; Teng, Y.S.; Kong, H.; Liu, Y.G.; Wu, X.L.; Hao, C.J.; Chen, W.; Duan, M.B.; et al. CD45(+)CD33(low)CD11b(dim) myeloid-derived suppressor cells suppress CD8(+) T cell activity via the IL-6/IL-8-arginase I axis in human gastric cancer. Cell Death Dis. 2018, 9, 763. [CrossRef] [PubMed]

107. Li, Y.M.; Liu, Z.Y.; Wang, J.C.; Yu, J.M.; Li, Z.C.; Yang, H.J.; Tang, J.; Chen, Z.N. Receptor-Interacting Protein Kinase 3 Deficiency Recruits Myeloid-Derived Suppressor Cells to Hepatocellular Carcinoma Through the Chemokine (C-X-C Motif) Ligand 1Chemokine (C-X-C Motif) Receptor 2 Axis. Hepatology 2019, 70, 1564-1581. [CrossRef] [PubMed]

108. Zhang, H.; Ye, Y.L.; Li, M.X.; Ye, S.B.; Huang, W.R.; Cai, T.T.; He, J.; Peng, J.Y.; Duan, T.H.; Cui, J.; et al. CXCL2/MIF-CXCR2 signaling promotes the recruitment of myeloid-derived suppressor cells and is correlated with prognosis in bladder cancer. Oncogene 2017, 36, 2095-2104. [CrossRef] [PubMed]

109. Yang, M.; Zhang, G.; Wang, Y.; He, M.; Xu, Q.; Lu, J.; Liu, H.; Xu, C. Tumour-associated neutrophils orchestrate intratumoural IL-8-driven immune evasion through Jagged2 activation in ovarian cancer. Br. J. Cancer 2020, 123, 1404-1416. [CrossRef] [PubMed]

110. Cheng, Y.; Mo, F.; Li, Q.; Han, X.; Shi, H.; Chen, S.; Wei, Y.; Wei, X. Targeting CXCR2 inhibits the progression of lung cancer and promotes therapeutic effect of cisplatin. Mol. Cancer 2021, 20, 62. [CrossRef]

111. Zhang, M.; Huang, L.; Ding, G.; Huang, H.; Cao, G.; Sun, X.; Lou, N.; Wei, Q.; Shen, T.; Xu, X.; et al. Interferon gamma inhibits CXCL8-CXCR2 axis mediated tumor-associated macrophages tumor trafficking and enhances anti-PD1 efficacy in pancreatic cancer. J. Immunother. Cancer 2020, 8, e000308. [CrossRef]

112. Chen, S.J.; Lian, G.D.; Li, J.J.; Zhang, Q.B.; Zeng, L.J.; Yang, K.G.; Huang, C.M.; Li, Y.Q.; Chen, Y.T.; Huang, K.H. Tumor-driven like macrophages induced by conditioned media from pancreatic ductal adenocarcinoma promote tumor metastasis via secreting IL-8. Cancer Med. 2018, 7, 5679-5690. [CrossRef] [PubMed]

113. Yu, J.; Ren, X.; Chen, Y.; Liu, P.; Wei, X.; Li, H.; Ying, G.; Chen, K.; Winkler, H.; Hao, X. Dysfunctional activation of neurotensin/IL-8 pathway in hepatocellular carcinoma is associated with increased inflammatory response in microenvironment, more epithelial mesenchymal transition in cancer and worse prognosis in patients. PLoS ONE 2013, 8, e56069. [CrossRef] [PubMed]

114. Xiao, P.; Long, X.; Zhang, L.; Ye, Y.; Guo, J.; Liu, P.; Zhang, R.; Ning, J.; Yu, W.; Wei, F.; et al. Neurotensin/IL-8 pathway orchestrates local inflammatory response and tumor invasion by inducing M2 polarization of Tumor-Associated macrophages and epithelial-mesenchymal transition of hepatocellular carcinoma cells. Oncoimmunology 2018, 7, e1440166. [CrossRef] [PubMed]

115. Fu, X.T.; Dai, Z.; Song, K.; Zhang, Z.J.; Zhou, Z.J.; Zhou, S.L.; Zhao, Y.M.; Xiao, Y.S.; Sun, Q.M.; Ding, Z.B.; et al. Macrophagesecreted IL-8 induces epithelial-mesenchymal transition in hepatocellular carcinoma cells by activating the JAK2/STAT3/Snail pathway. Int. J. Oncol. 2015, 46, 587-596. [CrossRef] 
116. Zheng, T.; Ma, G.; Tang, M.; Li, Z.; Xu, R. IL-8 Secreted from M2 Macrophages Promoted Prostate Tumorigenesis via STAT3/MALAT1 Pathway. Int. J. Mol. Sci. 2018, 20, 98. [CrossRef]

117. Fang, W.; Ye, L.; Shen, L.; Cai, J.; Huang, F.; Wei, Q.; Fei, X.; Chen, X.; Guan, H.; Wang, W.; et al. Tumor-associated macrophages promote the metastatic potential of thyroid papillary cancer by releasing CXCL8. Carcinogenesis 2014, 35, 1780-1787. [CrossRef]

118. Huang, W.; Chen, Z.; Zhang, L.; Tian, D.; Wang, D.; Fan, D.; Wu, K.; Xia, L. Interleukin-8 Induces Expression of FOXC1 to Promote Transactivation of CXCR1 and CCL2 in Hepatocellular Carcinoma Cell Lines and Formation of Metastases in Mice. Gastroenterology 2015, 149, 1053-1067.e14. [CrossRef]

119. Ning, Y.; Cui, Y.; Li, X.; Cao, X.; Chen, A.; Xu, C.; Cao, J.; Luo, X. Co-culture of ovarian cancer stem-like cells with macrophages induced SKOV3 cells stemness via IL-8/STAT3 signaling. Biomed. Pharm. 2018, 103, 262-271. [CrossRef]

120. Ning, Y.; Feng, W.; Cao, X.; Ren, K.; Quan, M.; Chen, A.; Xu, C.; Qiu, Y.; Cao, J.; Li, X.; et al. Genistein inhibits stemness of SKOV3 cells induced by macrophages co-cultured with ovarian cancer stem-like cells through IL-8/STAT3 axis. J. Exp. Clin. Cancer Res. 2019, 38, 19. [CrossRef]

121. Wang, D.; Yang, L.; Yue, D.; Cao, L.; Li, L.; Wang, D.; Ping, Y.; Shen, Z.; Zheng, Y.; Wang, L.; et al. Macrophage-derived CCL22 promotes an immunosuppressive tumor microenvironment via IL-8 in malignant pleural effusion. Cancer Lett. 2019, 452, 244-253. [CrossRef]

122. Kai, K.; Moriyama, M.; Haque, A.; Hattori, T.; Chinju, A.; Hu, C.; Kubota, K.; Miyahara, Y.; Kakizoe-Ishiguro, N.; Kawano, S.; et al. Oral Squamous Cell Carcinoma Contributes to Differentiation of Monocyte-Derived Tumor-Associated Macrophages via PAI-1 and IL-8 Production. Int. J. Mol. Sci. 2021, 22, 9475. [CrossRef]

123. Wu, J.; Gao, F.X.; Wang, C.; Qin, M.; Han, F.; Xu, T.; Hu, Z.; Long, Y.; He, X.M.; Deng, X.; et al. IL-6 and IL-8 secreted by tumour cells impair the function of NK cells via the STAT3 pathway in oesophageal squamous cell carcinoma. J. Exp. Clin. Cancer Res. 2019, 38, 321. [CrossRef] [PubMed]

124. Palena, C.; Hamilton, D.H.; Fernando, R.I. Influence of IL-8 on the epithelial-mesenchymal transition and the tumor microenvironment. Future Oncol. 2012, 8, 713-722. [CrossRef]

125. Fernando, R.I.; Castillo, M.D.; Litzinger, M.; Hamilton, D.H.; Palena, C. IL-8 signaling plays a critical role in the epithelialmesenchymal transition of human carcinoma cells. Cancer Res. 2011, 71, 5296-5306. [CrossRef] [PubMed]

126. Ospina-Muñoz, N.; Vernot, J.P. Partial acquisition of stemness properties in tumorspheres obtained from interleukin-8-treated MCF-7 cells. Tumour. Biol. 2020, 42, 1010428320979438. [CrossRef] [PubMed]

127. Deng, F.; Weng, Y.; Li, X.; Wang, T.; Fan, M.; Shi, Q. Overexpression of IL-8 promotes cell migration via PI3K-Akt signaling pathway and EMT in triple-negative breast cancer. Pathol. Res. Pract. 2021, 223, 152824. [CrossRef] [PubMed]

128. Jin, F.; Miao, Y.; Xu, P.; Qiu, X. IL-8 regulates the stemness properties of cancer stem cells in the small-cell lung cancer cell line H446. OncoTargets Ther. 2018, 11, 5723-5731. [CrossRef]

129. Hsu, P.C.; Chen, Y.H.; Cheng, C.F.; Kuo, C.Y.; Sytwu, H.K. Interleukin-6 and Interleukin-8 Regulate STAT3 Activation Migration/Invasion and EMT in Chrysophanol-Treated Oral Cancer Cell Lines. Life 2021, 11, 423. [CrossRef]

130. Taki, M.; Abiko, K.; Baba, T.; Hamanishi, J.; Yamaguchi, K.; Murakami, R.; Yamanoi, K.; Horikawa, N.; Hosoe, Y.; Nakamura, E.; et al. Snail promotes ovarian cancer progression by recruiting myeloid-derived suppressor cells via CXCR2 ligand upregulation. Nat. Commun. 2018, 9, 1685. [CrossRef]

131. Choi, H.S.; Kim, J.H.; Kim, S.L.; Lee, D.S. Disruption of the NF-кB/IL-8 Signaling Axis by Sulconazole Inhibits Human Breast Cancer Stem Cell Formation. Cells 2019, 8, 1007. [CrossRef]

132. Hasan, T.; Caragher, S.P.; Shireman, J.M.; Park, C.H.; Atashi, F.; Baisiwala, S.; Lee, G.; Guo, D.; Wang, J.Y.; Dey, M.; et al Interleukin-8/CXCR2 signaling regulates therapy-induced plasticity and enhances tumorigenicity in glioblastoma. Cell Death Dis. 2019, 10, 292. [CrossRef]

133. Shimizu, M.; Tanaka, N. IL-8-induced O-GlcNAc modification via GLUT3 and GFAT regulates cancer stem cell-like properties in colon and lung cancer cells. Oncogene 2019, 38, 1520-1533. [CrossRef]

134. Kawano, M.; Tanaka, K.; Itonaga, I.; Iwasaki, T.; Tsumura, H. Interaction between human osteosarcoma and mesenchymal stem cells via an interleukin-8 signaling loop in the tumor microenvironment. Cell Commun. Signal. 2018, 16, 13. [CrossRef] [PubMed]

135. Du, L.; Han, X.G.; Tu, B.; Wang, M.Q.; Qiao, H.; Zhang, S.H.; Fan, Q.M.; Tang, T.T. CXCR1/Akt signaling activation induced by mesenchymal stem cell-derived IL-8 promotes osteosarcoma cell anoikis resistance and pulmonary metastasis. Cell Death Dis. 2018, 9, 714. [CrossRef] [PubMed]

136. Han, X.G.; Du, L.; Qiao, H.; Tu, B.; Wang, Y.G.; Qin, A.; Dai, K.R.; Fan, Q.M.; Tang, T.T. CXCR1 knockdown improves the sensitivity of osteosarcoma to cisplatin. Cancer Lett. 2015, 369, 405-415. [CrossRef]

137. Sparmann, A.; Bar-Sagi, D. Ras-induced interleukin-8 expression plays a critical role in tumor growth and angiogenesis. Cancer Cell 2004, 6, 447-458. [CrossRef] [PubMed]

138. Omi, K.; Matsuo, Y.; Ueda, G.; Aoyama, Y.; Kato, T.; Hayashi, Y.; Imafuji, H.; Saito, K.; Tsuboi, K.; Morimoto, M.; et al. Escin inhibits angiogenesis by suppressing interleukin-8 and vascular endothelial growth factor production by blocking nuclear factor- $\kappa B$ activation in pancreatic cancer cell lines. Oncol. Rep. 2021, 45, 1-9. [CrossRef] [PubMed]

139. Matsuo, Y.; Raimondo, M.; Woodward, T.A.; Wallace, M.B.; Gill, K.R.; Tong, Z.; Burdick, M.D.; Yang, Z.; Strieter, R.M.; Hoffman, R.M.; et al. CXC-chemokine/CXCR2 biological axis promotes angiogenesis in vitro and in vivo in pancreatic cancer. Int. J. Cancer 2009, 125, 1027-1037. [CrossRef] [PubMed] 
140. Imafuji, H.; Matsuo, Y.; Ueda, G.; Omi, K.; Hayashi, Y.; Saito, K.; Tsuboi, K.; Morimoto, M.; Koide, S.; Ogawa, R.; et al. Acquisition of gemcitabine resistance enhances angiogenesis via upregulation of IL-8 production in pancreatic cancer. Oncol. Rep. 2019, 41, 3508-3516. [CrossRef]

141. Wang, J.; Hu, W.; Wu, X.; Wang, K.; Yu, J.; Luo, B.; Luo, G.; Wang, W.; Wang, H.; Li, J.; et al. CXCR1 promotes malignant behavior of gastric cancer cells in vitro and in vivo in AKT and ERK1/2 phosphorylation. Int. J. Oncol. 2016, 48, 2184-2196. [CrossRef]

142. Shamaladevi, N.; Lyn, D.A.; Escudero, D.O.; Lokeshwar, B.L. CXC receptor-1 silencing inhibits androgen-independent prostate cancer. Cancer Res. 2009, 69, 8265-8274. [CrossRef]

143. Bonavia, R.; Inda, M.M.; Vandenberg, S.; Cheng, S.Y.; Nagane, M.; Hadwiger, P.; Tan, P.; Sah, D.W.; Cavenee, W.K.; Furnari, F.B. EGFRvIII promotes glioma angiogenesis and growth through the NF- $\mathrm{B}$, interleukin-8 pathway. Oncogene 2012, 31, 4054-4066. [CrossRef] [PubMed]

144. Paulitti, A.; Andreuzzi, E.; Bizzotto, D.; Pellicani, R.; Tarticchio, G.; Marastoni, S.; Pastrello, C.; Jurisica, I.; Ligresti, G.; Bucciotti, F.; et al. The ablation of the matricellular protein EMILIN2 causes defective vascularization due to impaired EGFR-dependent IL-8 production affecting tumor growth. Oncogene 2018, 37, 3399-3414. [CrossRef] [PubMed]

145. Vijay, V.; Miller, R.; Vue, G.S.; Pezeshkian, M.B.; Maywood, M.; Ast, A.M.; Drusbosky, L.M.; Pompeu, Y.; Salgado, A.D.; Lipten, S.D.; et al. Interleukin-8 blockade prevents activated endothelial cell mediated proliferation and chemoresistance of acute myeloid leukemia. Leuk. Res. 2019, 84, 106180. [CrossRef] [PubMed]

146. Li, W.; Lin, S.; Li, W.; Wang, W.; Li, X.; Xu, D. IL-8 interacts with metadherin promoting proliferation and migration in gastric cancer. Biochem. Biophys. Res. Commun. 2016, 478, 1330-1337. [CrossRef] [PubMed]

147. Shao, N.; Lu, Z.; Zhang, Y.; Wang, M.; Li, W.; Hu, Z.; Wang, S.; Lin, Y. Interleukin-8 upregulates integrin $\beta 3$ expression and promotes estrogen receptor-negative breast cancer cell invasion by activating the PI3K/Akt/NF-кB pathway. Cancer Lett. 2015, 364, 165-172. [CrossRef]

148. Sun, F.; Wang, J.; Sun, Q.; Li, F.; Gao, H.; Xu, L.; Zhang, J.; Sun, X.; Tian, Y.; Zhao, Q.; et al. Interleukin-8 promotes integrin $\beta 3$ upregulation and cell invasion through PI3K/Akt pathway in hepatocellular carcinoma. J. Exp. Clin. Cancer Res. 2019, 38, 449. [CrossRef]

149. Sun, Q.; Sun, F.; Wang, B.; Liu, S.; Niu, W.; Liu, E.; Peng, C.; Wang, J.; Gao, H.; Liang, B.; et al. Interleukin-8 promotes cell migration through integrin $\alpha \mathrm{v} \beta 6$ upregulation in colorectal cancer. Cancer Lett. 2014, 354, 245-253. [CrossRef]

150. Siu, M.K.Y.; Jiang, Y.X.; Wang, J.J.; Leung, T.H.Y.; Ngu, S.F.; Cheung, A.N.Y.; Ngan, H.Y.S.; Chan, K.K.L. PDK1 promotes ovarian cancer metastasis by modulating tumor-mesothelial adhesion, invasion, and angiogenesis via $\alpha 5 \beta 1$ integrin and JNK/IL- 8 signaling. Oncogenesis 2020, 9, 24. [CrossRef] [PubMed]

151. Urbantat, R.M.; Blank, A.; Kremenetskaia, I.; Vajkoczy, P.; Acker, G.; Brandenburg, S. The CXCL2/IL8/CXCR2 Pathway Is Relevant for Brain Tumor Malignancy and Endothelial Cell Function. Int. J. Mol. Sci. 2021, 22, 2634. [CrossRef] [PubMed]

152. Yang, J.W.; Murray, B.; Barbier-Torres, L.; Liu, T.; Liu, Z.; Yang, H.; Fan, W.; Wang, J.; Li, Y.; Seki, E.; et al. The mitochondrial chaperone Prohibitin 1 negatively regulates interleukin-8 in human liver cancers. J. Biol. Chem. 2019, 294, 1984-1996. [CrossRef] [PubMed]

153. Huang, D.; Ding, Y.; Zhou, M.; Rini, B.I.; Petillo, D.; Qian, C.N.; Kahnoski, R.; Futreal, P.A.; Furge, K.A.; Teh, B.T. Interleukin-8 mediates resistance to antiangiogenic agent sunitinib in renal cell carcinoma. Cancer Res. 2010, 70, 1063-1071. [CrossRef] [PubMed]

154. Wang, H.C.; Lin, Y.L.; Hsu, C.C.; Chao, Y.J.; Hou, Y.C.; Chiu, T.J.; Huang, P.H.; Tang, M.J.; Chen, L.T.; Shan, Y.S. Pancreatic stellate cells activated by mutant KRAS-mediated PAI-1 upregulation foster pancreatic cancer progression via IL-8. Theranostics 2019, 9 , 7168-7183. [CrossRef] [PubMed]

155. Khazali, A.S.; Clark, A.M.; Wells, A. Inflammatory cytokine IL-8/CXCL8 promotes tumour escape from hepatocyte-induced dormancy. Br. J. Cancer 2018, 118, 566-576. [CrossRef]

156. Callaway, C.S.; Delitto, A.E.; Patel, R.; Nosacka, R.L.; D'Lugos, A.C.; Delitto, D.; Deyhle, M.R.; Trevino, J.G.; Judge, S.M.; Judge, A.R. IL-8 Released from Human Pancreatic Cancer and Tumor-Associated Stromal Cells Signals through a CXCR2-ERK1/2 Axis to Induce Muscle Atrophy. Cancers 2019, 11, 1863. [CrossRef]

157. Mi, Y.; Mu, L.; Huang, K.; Hu, Y.; Yan, C.; Zhao, H.; Ma, C.; Li, X.; Tao, D.; Qin, J. Hypoxic colorectal cancer cells promote metastasis of normoxic cancer cells depending on IL-8/p65 signaling pathway. Cell Death Dis. 2020, 11, 610. [CrossRef] [PubMed]

158. Wang, Y.; Zhao, M.; He, S.; Luo, Y.; Zhao, Y.; Cheng, J.; Gong, Y.; Xie, J.; Wang, Y.; Hu, B.; et al. Necroptosis regulates tumor repopulation after radiotherapy via RIP1/RIP3/MLKL/JNK/IL8 pathway. J. Exp. Clin. Cancer Res. 2019, 38, 461. [CrossRef]

159. Jayatilaka, H.; Tyle, P.; Chen, J.J.; Kwak, M.; Ju, J.; Kim, H.J.; Lee, J.S.H.; Wu, P.H.; Gilkes, D.M.; Fan, R.; et al. Synergistic IL-6 and IL-8 paracrine signalling pathway infers a strategy to inhibit tumour cell migration. Nat. Commun. 2017, 8, 15584. [CrossRef] [PubMed]

160. Fu, X.; Jeselsohn, R.; Pereira, R.; Hollingsworth, E.F.; Creighton, C.J.; Li, F.; Shea, M.; Nardone, A.; De Angelis, C.; Heiser, L.M.; et al. FOXA1 overexpression mediates endocrine resistance by altering the ER transcriptome and IL- 8 expression in ER-positive breast cancer. Proc. Natl. Acad. Sci. USA 2016, 113, E6600-E6609. [CrossRef]

161. Chen, W.T.; Ebelt, N.D.; Stracker, T.H.; Xhemalce, B.; Van Den Berg, C.L.; Miller, K.M. ATM regulation of IL-8 links oxidative stress to cancer cell migration and invasion. Elife 2015, 4, e07270. [CrossRef]

162. Ahn, S.H.; Park, H.; Ahn, Y.H.; Kim, S.; Cho, M.S.; Kang, J.L.; Choi, Y.H. Necrotic cells influence migration and invasion of glioblastoma via NF-kB/AP-1-mediated IL-8 regulation. Sci. Rep. 2016, 6, 24552. [CrossRef] [PubMed] 
163. Xu, Q.; Ma, H.; Chang, H.; Feng, Z.; Zhang, C.; Yang, X. The interaction of interleukin-8 and PTEN inactivation promotes the malignant progression of head and neck squamous cell carcinoma via the STAT3 pathway. Cell Death Dis. 2020, 11, 405. [CrossRef] [PubMed]

164. White, J.R.; Lee, J.M.; Young, P.R.; Hertzberg, R.P.; Jurewicz, A.J.; Chaikin, M.A.; Widdowson, K.; Foley, J.J.; Martin, L.D.; Griswold, D.E.; et al. Identification of a potent, selective non-peptide CXCR2 antagonist that inhibits interleukin-8-induced neutrophil migration. J. Biol. Chem. 1998, 273, 10095-10098. [CrossRef]

165. Kim, S.; You, D.; Jeong, Y.; Yoon, S.Y.; Kim, S.A.; Kim, S.W.; Nam, S.J.; Lee, J.E. WNT5A augments cell invasiveness by inducing CXCL8 in HER2-positive breast cancer cells. Cytokine 2020, 135, 155213. [CrossRef]

166. Yung, M.M.; Tang, H.W.; Cai, P.C.; Leung, T.H.; Ngu, S.F.; Chan, K.K.; Xu, D.; Yang, H.; Ngan, H.Y.; Chan, D.W. GRO- $\alpha$ and IL-8 enhance ovarian cancer metastatic potential via the CXCR2-mediated TAK1/NFKB signaling cascade. Theranostics 2018, 8 , 1270-1285. [CrossRef] [PubMed]

167. Cheng, J.; Li, Y.; Liu, S.; Jiang, Y.; Ma, J.; Wan, L.; Li, Q.; Pang, T. CXCL8 derived from mesenchymal stromal cells supports survival and proliferation of acute myeloid leukemia cells through the PI3K/AKT pathway. FASEB J. 2019, 33, 4755-4764. [CrossRef] [PubMed]

168. Liu, X.; Lan, T.; Mo, F.; Yang, J.; Wei, Y.; Wei, X. Antitumor and Radiosensitization Effects of a CXCR2 Inhibitor in Nasopharyngeal Carcinoma. Front. Cell Dev. Biol. 2021, 9, 689613. [CrossRef]

169. Bertini, R.; Allegretti, M.; Bizzarri, C.; Moriconi, A.; Locati, M.; Zampella, G.; Cervellera, M.N.; Di Cioccio, V.; Cesta, M.C.; Galliera, E.; et al. Noncompetitive allosteric inhibitors of the inflammatory chemokine receptors CXCR1 and CXCR2: Prevention of reperfusion injury. Proc. Natl. Acad. Sci. USA 2004, 101, 11791-11796. [CrossRef]

170. Ruffini, P.A. The CXCL8-CXCR1/2 Axis as a Therapeutic Target in Breast Cancer Stem-Like Cells. Front. Oncol. 2019, 9, 40. [CrossRef] [PubMed]

171. Chapman, R.W.; Minnicozzi, M.; Celly, C.S.; Phillips, J.E.; Kung, T.T.; Hipkin, R.W.; Fan, X.; Rindgen, D.; Deno, G.; Bond, R.; et al. A novel, orally active CXCR1/2 receptor antagonist, Sch527123, inhibits neutrophil recruitment, mucus production, and goblet cell hyperplasia in animal models of pulmonary inflammation. J. Pharm. Exp. Ther. 2007, 322, 486-493. [CrossRef] [PubMed]

172. Singh, S.; Sadanandam, A.; Nannuru, K.C.; Varney, M.L.; Mayer-Ezell, R.; Bond, R.; Singh, R.K. Small-molecule antagonists for CXCR2 and CXCR1 inhibit human melanoma growth by decreasing tumor cell proliferation, survival, and angiogenesis. Clin. Cancer Res. 2009, 15, 2380-2386. [CrossRef] [PubMed]

173. Nicholls, D.J.; Wiley, K.; Dainty, I.; MacIntosh, F.; Phillips, C.; Gaw, A.; Mårdh, C.K. Pharmacological characterization of AZD5069, a slowly reversible CXC chemokine receptor 2 antagonist. J. Pharm. Exp. Ther. 2015, 353, 340-350. [CrossRef] [PubMed]

174. Di Mitri, D.; Mirenda, M.; Vasilevska, J.; Calcinotto, A.; Delaleu, N.; Revandkar, A.; Gil, V.; Boysen, G.; Losa, M.; Mosole, S.; et al. Re-education of Tumor-Associated Macrophages by CXCR2 Blockade Drives Senescence and Tumor Inhibition in Advanced Prostate Cancer. Cell Rep. 2019, 28, 2156-2168.e5. [CrossRef] [PubMed]

175. Busch-Petersen, J.; Carpenter, D.C.; Burman, M.; Foley, J.; Hunsberger, G.E.; Kilian, D.J.; Salmon, M.; Mayer, R.J.; Yonchuk, J.G.; Tal-Singer, R. Danirixin: A Reversible and Selective Antagonist of the CXC Chemokine Receptor 2. J. Pharm. Exp. Ther. 2017, 362, 338-346. [CrossRef] [PubMed]

176. Miller, B.E.; Smart, K.; Mistry, S.; Ambery, C.L.; Bloomer, J.C.; Connolly, P.; Sanderson, D.; Shreeves, T.; Smith, R.; Lazaar, A.L. The pharmacokinetics of conventional and bioenhanced tablet formulations of danirixin (GSK1325756) following oral administration in healthy, elderly, human volunteers. Eur. J. Drug Metab. Pharm. 2014, 39, 173-181. [CrossRef]

177. Miller, B.E.; Mistry, S.; Smart, K.; Connolly, P.; Carpenter, D.C.; Cooray, H.; Bloomer, J.C.; Tal-Singer, R.; Lazaar, A.L. The pharmacokinetics and pharmacodynamics of danirixin (GSK1325756) - A selective CXCR2 antagonist-in healthy adult subjects. BMC Pharm. Toxicol. 2015, 16, 18. [CrossRef]

178. Nie, G.; Cao, X.; Mao, Y.; Lv, Z.; Lv, M.; Wang, Y.; Wang, H.; Liu, C. Tumor-associated macrophages-mediated CXCL8 infiltration enhances breast cancer metastasis: Suppression by Danirixin. Int. Immunopharmacol. 2021, 95, 107153. [CrossRef]

179. Kargl, J.; Zhu, X.; Zhang, H.; Yang, G.H.Y.; Friesen, T.J.; Shipley, M.; Maeda, D.Y.; Zebala, J.A.; McKay-Fleisch, J.; Meredith, G.; et al. Neutrophil content predicts lymphocyte depletion and anti-PD1 treatment failure in NSCLC. JCI Insight 2019, 4, e130850. [CrossRef]

180. Yang, J.; Yan, C.; Vilgelm, A.E.; Chen, S.C.; Ayers, G.D.; Johnson, C.A.; Richmond, A. Targeted Deletion of CXCR2 in Myeloid Cells Alters the Tumor Immune Environment to Improve Antitumor Immunity. Cancer Immunol. Res. 2021, 9, 200-213. [CrossRef]

181. Huang, S.; Mills, L.; Mian, B.; Tellez, C.; McCarty, M.; Yang, X.D.; Gudas, J.M.; Bar-Eli, M. Fully humanized neutralizing antibodies to interleukin-8 (ABX-IL8) inhibit angiogenesis, tumor growth, and metastasis of human melanoma. Am. J. Pathol. 2002, 161, 125-134. [CrossRef]

182. Mian, B.M.; Dinney, C.P.; Bermejo, C.E.; Sweeney, P.; Tellez, C.; Yang, X.D.; Gudas, J.M.; McConkey, D.J.; Bar-Eli, M. Fully human anti-interleukin 8 antibody inhibits tumor growth in orthotopic bladder cancer xenografts via down-regulation of matrix metalloproteases and nuclear factor-kappaB. Clin. Cancer Res. 2003, 9, 3167-3175. [PubMed]

183. Bilusic, M.; Heery, C.R.; Collins, J.M.; Donahue, R.N.; Palena, C.; Madan, R.A.; Karzai, F.; Marté, J.L.; Strauss, J.; Gatti-Mays, M.E.; et al. Phase I trial of HuMax-IL8 (BMS-986253), an anti-IL-8 monoclonal antibody, in patients with metastatic or unresectable solid tumors. J. Immunother. Cancer 2019, 7, 240. [CrossRef] [PubMed]

184. Hou, A.J.; Chen, L.C.; Chen, Y.Y. Navigating CAR-T cells through the solid-tumour microenvironment. Nat. Rev. Drug Discov. 2021, 20, 531-550. [CrossRef] [PubMed] 
185. Jin, L.; Tao, H.; Karachi, A.; Long, Y.; Hou, A.Y.; Na, M.; Dyson, K.A.; Grippin, A.J.; Deleyrolle, L.P.; Zhang, W.; et al. CXCR1- or CXCR2-modified CAR T cells co-opt IL-8 for maximal antitumor efficacy in solid tumors. Nat. Commun. 2019, 10, 4016. [CrossRef] [PubMed]

186. Kim, S.I.; Cassella, C.R.; Byrne, K.T. Tumor Burden and Immunotherapy: Impact on Immune Infiltration and Therapeutic Outcomes. Front. Immunol. 2020, 11, 629722. [CrossRef] [PubMed]

187. Kayser, A.S. Functional imaging. Handb. Clin. Neurol. 2019, 163, 61-72. [PubMed]

188. Matsumoto, K.I.; Mitchell, J.B.; Krishna, M.C. Multimodal Functional Imaging for Cancer/Tumor Microenvironments Based on MRI, EPRI, and PET. Molecules 2021, 26, 1614. [CrossRef]

189. Sanmamed, M.F.; Carranza-Rua, O.; Alfaro, C.; Oñate, C.; Martín-Algarra, S.; Perez, G.; Landazuri, S.F.; Gonzalez, A.; Gross, S.; Rodriguez, I.; et al. Serum interleukin-8 reflects tumor burden and treatment response across malignancies of multiple tissue origins. Clin. Cancer Res. 2014, 20, 5697-5707. [CrossRef]

190. Sanmamed, M.F.; Perez-Gracia, J.L.; Schalper, K.A.; Fusco, J.P.; Gonzalez, A.; Rodriguez-Ruiz, M.E.; Oñate, C.; Perez, G.; Alfaro, C.; Martín-Algarra, S.; et al. Changes in serum interleukin-8 (IL-8) levels reflect and predict response to anti-PD-1 treatment in melanoma and non-small-cell lung cancer patients. Ann. Oncol. 2017, 28, 1988-1995. [CrossRef]

191. Merz, V.; Zecchetto, C.; Santoro, R.; Simionato, F.; Sabbadini, F.; Mangiameli, D.; Piro, G.; Cavaliere, A.; Deiana, M.; Valenti, M.T.; et al. Plasma IL8 Is a Biomarker for TAK1 Activation and Predicts Resistance to Nanoliposomal Irinotecan in Patients with Gemcitabine-Refractory Pancreatic Cancer. Clin. Cancer Res. 2020, 26, 4661-4669. [CrossRef]

192. Öcal, O.; Schütte, K.; Kupčinskas, J.; Morkunas, E.; Jurkeviciute, G.; de Toni, E.N.; Ben Khaled, N.; Berg, T.; Malfertheiner, P.; Klümpen, H.J.; et al. Baseline Interleukin- 6 and -8 predict response and survival in patients with advanced hepatocellular carcinoma treated with sorafenib monotherapy: An exploratory post hoc analysis of the SORAMIC trial. J. Cancer Res. Clin. Oncol. 2021. [CrossRef] [PubMed]

193. Schalper, K.A.; Carleton, M.; Zhou, M.; Chen, T.; Feng, Y.; Huang, S.P.; Walsh, A.M.; Baxi, V.; Pandya, D.; Baradet, T.; et al. Elevated serum interleukin-8 is associated with enhanced intratumor neutrophils and reduced clinical benefit of immune-checkpoint inhibitors. Nat. Med. 2020, 26, 688-692. [CrossRef] [PubMed]

194. Yuen, K.C.; Liu, L.F.; Gupta, V.; Madireddi, S.; Keerthivasan, S.; Li, C.; Rishipathak, D.; Williams, P.; Kadel, E.E., 3rd; Koeppen, H.; et al. High systemic and tumor-associated IL-8 correlates with reduced clinical benefit of PD-L1 blockade. Nat. Med. 2020, 26, 693-698. [CrossRef] [PubMed] 